\title{
معالم الفكر التربويّ عند ابن خلدون
}

\section{علي محمد جبران}

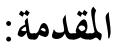

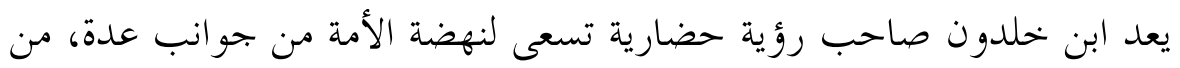

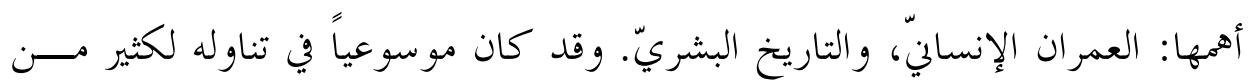

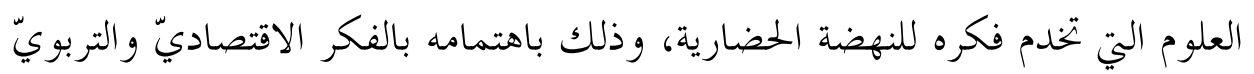

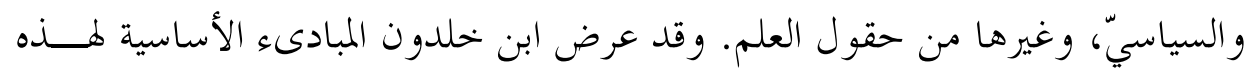

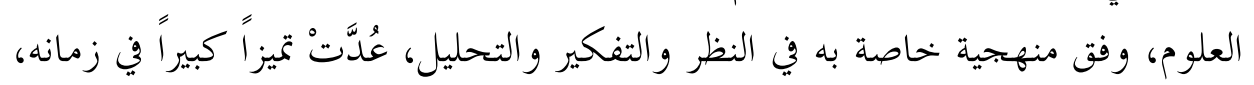

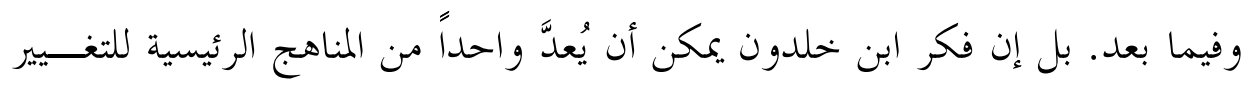
والإصلاح. و وفيما بعل.

ولأن مناهج التغيير والإصلاح الفكريّ عبر العصور لا يمكن أن يتم استيعاها، إلا

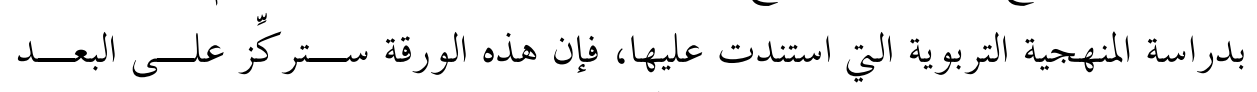

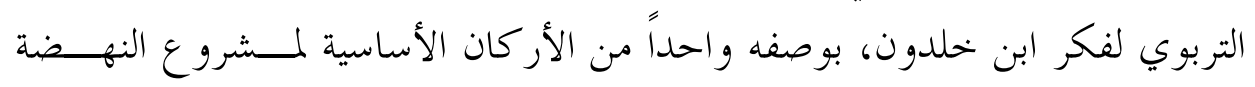

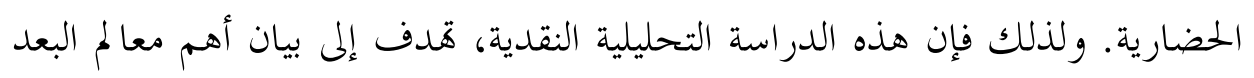

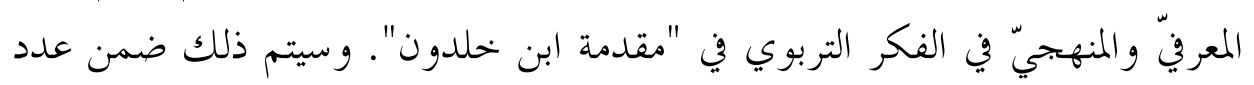

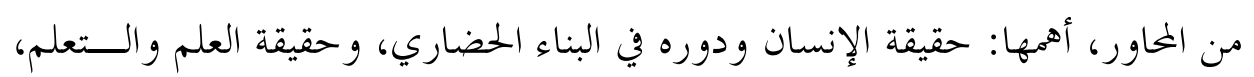

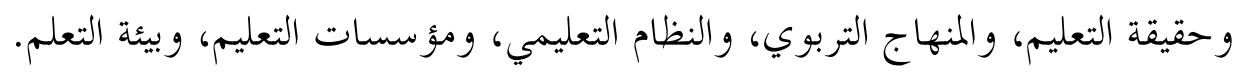
وهدف الورقة، على وجه التحديد، إلى بيان طبيعة الإسهام الحقيقي الذي أضافه

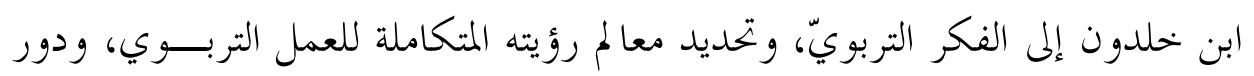

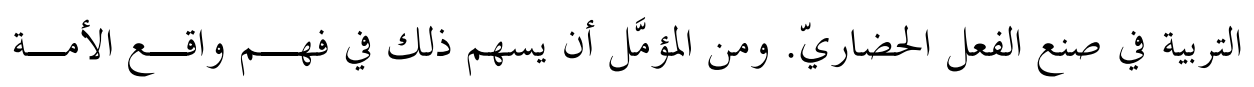
jubran30@yu.edu.jo. دكتوراه في الإدارة التربوية، أستاذ مساعد، جامعة اليرموك، الأردن. 
المعاصر، وفي ضرورة إيجاد منهجية علمية لرفع مستوى الوعي بالمناهج الفكرية، الــتي تصبو إلى صنع التغيير والإصلاح في الأمة.

أولاً: طبيعة الإنسان ودوره في البناء الحضاري:

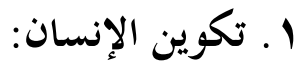

ينطلق ابن خلدون في نظرته إلى الإنسان من منهجية إسلامية واضحة، تتمثل في

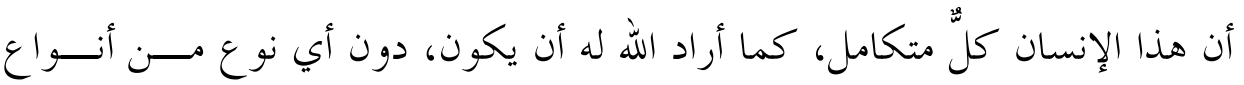
التجزيء أو الفصل، ويبين "أنّ الإنسان مركّب من جز أين: أحدها هما جسمانّ، و والآخر

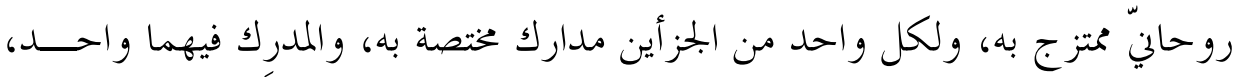

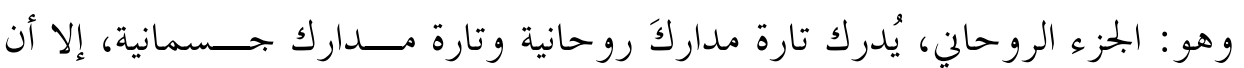
المدارك الروحانية يدركها بذاته بغير واسطة، والمدارك الجسمانية بواسطة آلات الجسم

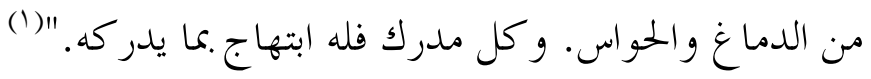

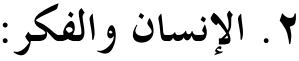

من زاوية أخرى، ومن معين التصور الإسلامي نفسه، يــــى ابــن خلـــــون أن أن الإنسان يتميّز عن باقي الكائنات الحية التي وهبها الله صفة الحياة، بفكره السامي الذي

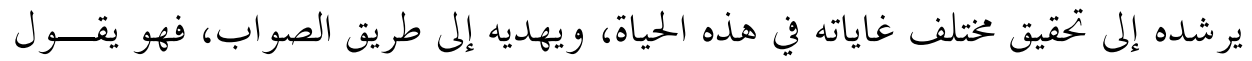
في ذلك: "إنّ الإنسان قد شار كته جميع الحيوانات في حيو انيته، من: الحس، و والحركة، و الغذاء، وغير ذلك. وإنما تميّز عنها بالفكر الذي يهتدي به لتحصيل معاشه، و التعاون

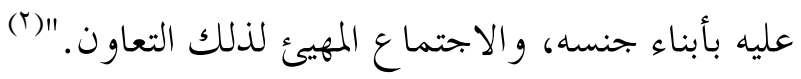

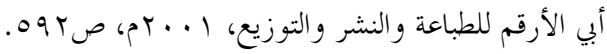

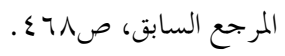


هذا فيما يتعلق بقضايا الحياة، وأما الآخرة فإن الإنسان بفكره كذلك يتمكن من

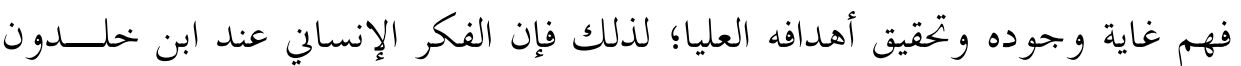

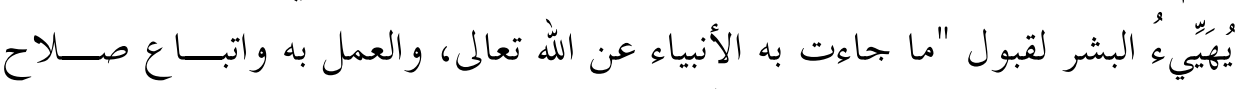

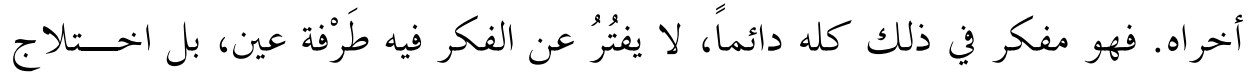

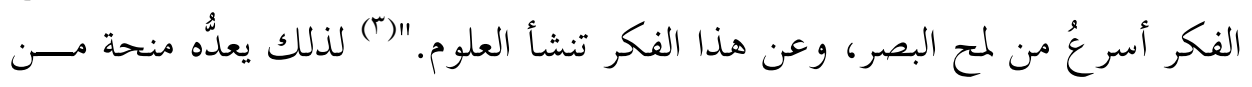

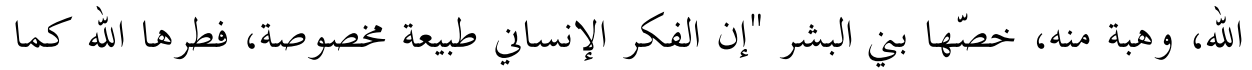

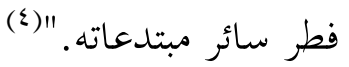

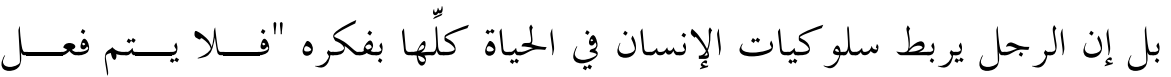

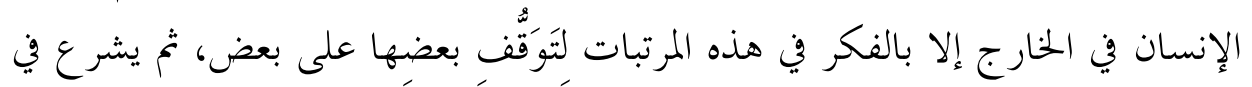

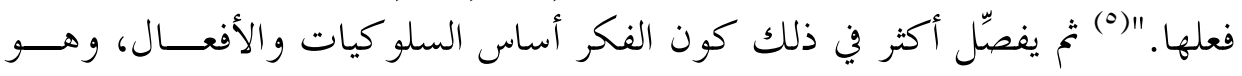

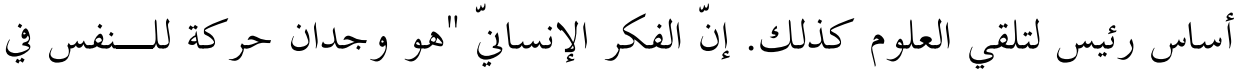

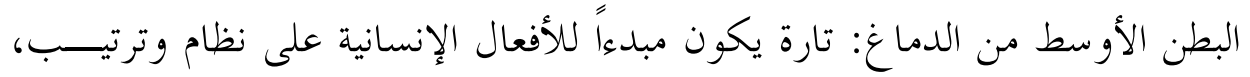

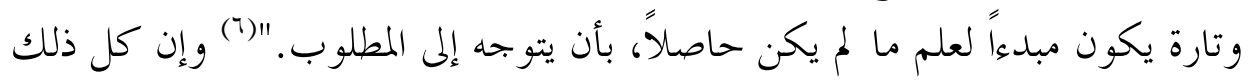

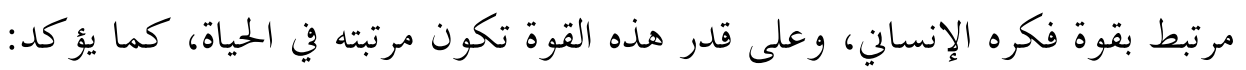

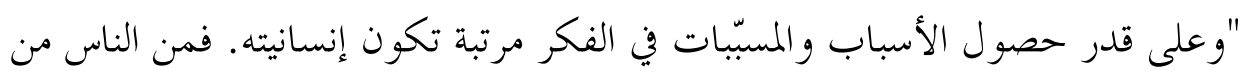

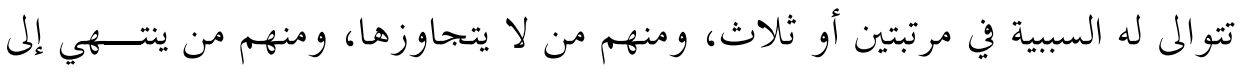

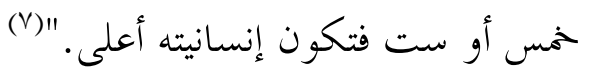

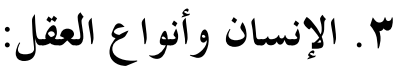

وبناء على ما تقدم، فإنّ الإنسان عند ابن خلدون يستخدم أنواعاً ثلاثة للنـششاط

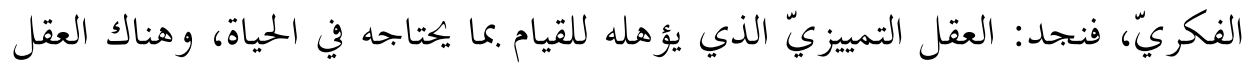

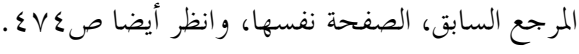

$$
\begin{aligned}
& \text { المرجع السابق، صع ـ م. } \\
& \text { المرجع السابق، الصفحة نفسها وانظر أيضاص صـ ـ } 0 .
\end{aligned}
$$

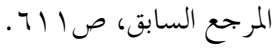

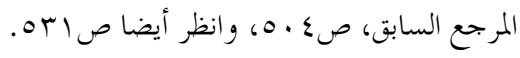


التجرييّ الذي يتعلق بالآراء وما يحتاجه في معاملة بين البشر، ثم العقل النظريّ الــــي يؤهّله للنظر إلى طبيعة الوجود من حوله، يقول في ذلك: "إن الله تعالى ميّز الإنــسـان بالفكر الذي جعل له، يوقع به أفعاله على انتظام، وهو العقل التمييزيّ، أو يقتنص به العلم بالآراء و المصالح و المفاسد من أبناء جنسه، وهو العقل التجريّيّ، أو يكصل به في تصور الموجودات غائباً وشاهداً، على ما هي عليه، وهو العقل النظريّ. وهذا الفكر إناء إنما يجصل له بعد كمال الحيوانية فيه، ويبدأ من التمييز، فهو قبل التمييز خَلْوُوٌ من العلم بالجملة، معدودٌ من الحيوانات، لاحق .مبدئه في التكوين، من النطفة والعلقة والمضغة.

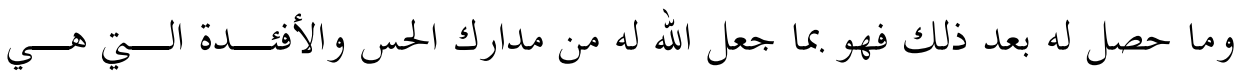
(^)" الفكر

\section{ع ـ الإنسان المستخلف:}

بعد ذلك يذكر ابن خلدون أنَّ الله قد سخر لإِنسان كلَّ شيء في هذه الحيـــاة "ولما كانت الحواس المعتبرة في عالم الكائنات هي المنتظمة، وغير المنتظمة إنما هي تبــع لئع لها، اندرجت حينئ أفعال الحيوانات فيها، فكانت مسخرة للبشر. و استولت أفعــال البشر على عالم الحو ادث .ما فيه، فكان كله في طاعته وتسخره."(9) ليحدد بعد ذلك

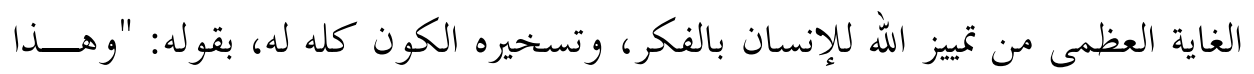

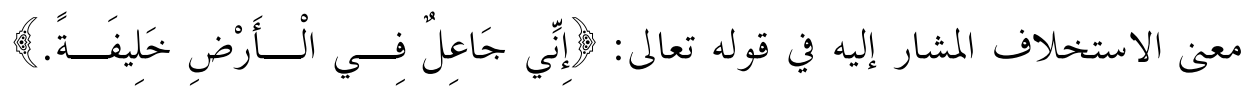
(البقرة: • ب) فهذا الفكر هو الخاصة البشرية التي تميّز هـا البــشر عــن غــيره مــن

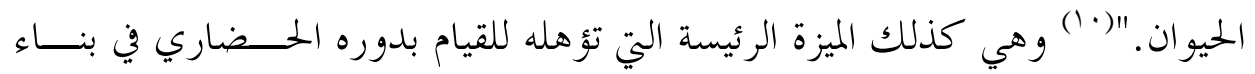
العمران البشري، الذي يدور فكر ابن خلدون الكليّ حوله.

$$
\begin{aligned}
& \text { المرجع السابق، ص9.0.0. }
\end{aligned}
$$

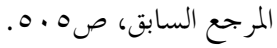

$$
\begin{aligned}
& \text { المرجع السابق، الصفحة نفسها. }
\end{aligned}
$$




\section{• (الإنسان الاجتماعي:}

وتحقيقاً لهذه الغاية الكبرى، فإنّ الإنسان عند ابن خلدون اجتماعيٌّ بطبعه الـــذي

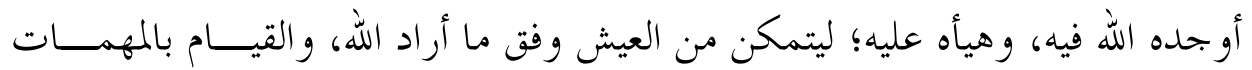

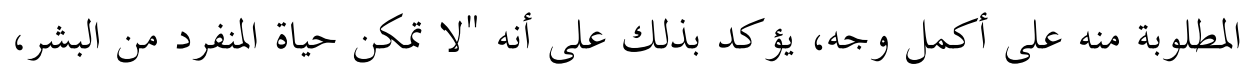
ولا يتم وجوده إلا مع أبناء جنسه؛ وذلك لما هو عليه من العجز عن استكمال و وجوده

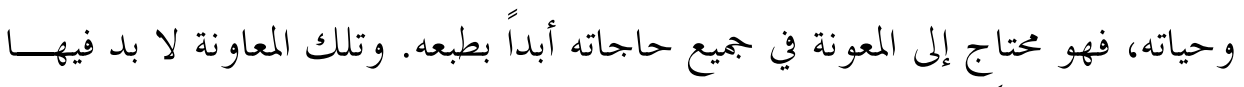

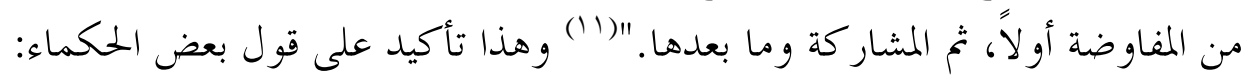
إن الإنسان مَدليّ بطبعه.

\section{7. الإنسان و حاجته لعو الم ثلاثة:}

إن الإنسان في نظر ابن خلدون يعيش في عوالم ثلاثة. أولها: عالم الحس، "ونعتبره

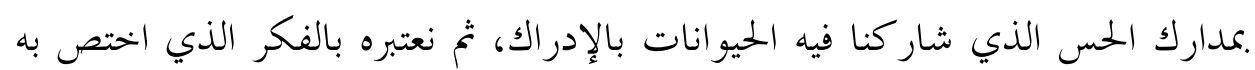

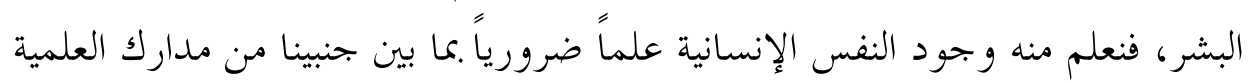

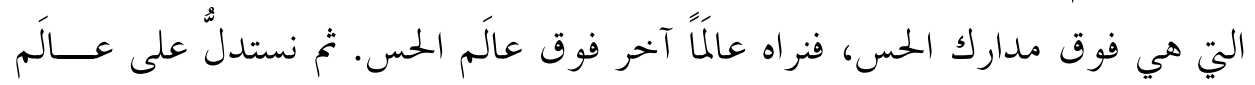

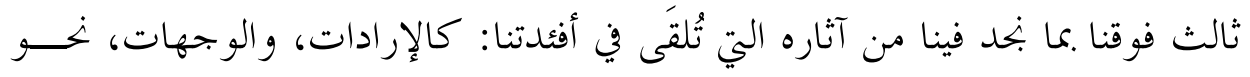

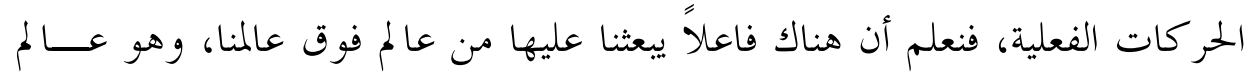

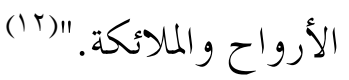

ثانياً: حقيقة المعلِّم و المتعلِّم:

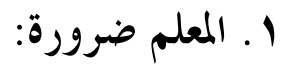

ينظر ابن خلدون إلى المعلم أنه ضرورة من الضرورات الأساسية للعملية التربوية،

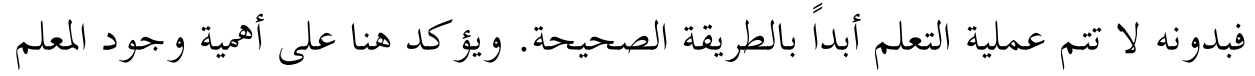


حقيقة؛ ليشرف بنفسه على إيصال المعلومة إلى طالبها، بقوله: "إلا أن حصول المَلكات

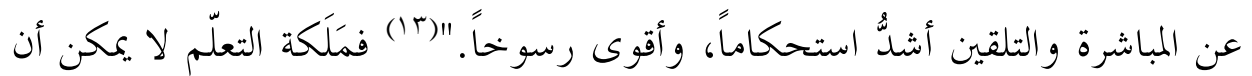

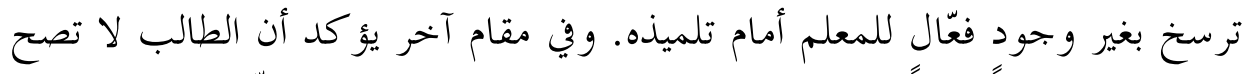

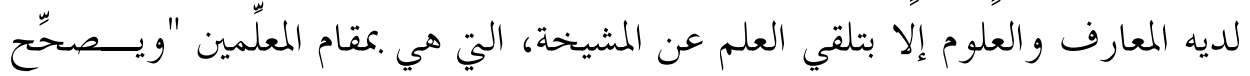
معارفه ويميزها عن سواها مع تقوية ملكته بالمباشرة و التلقين و كثرقما من المشيخة عند

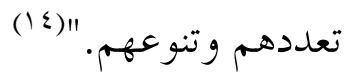

\section{Y . نوعية المعلِّم و تنوٌٌع المعلِّمين:}

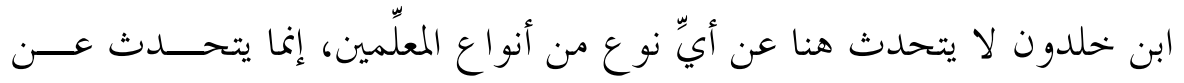

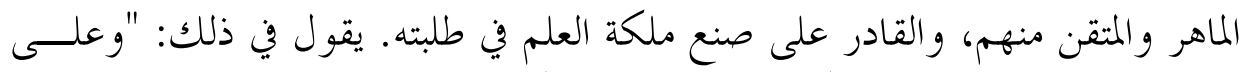

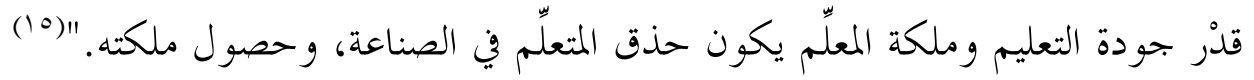
و وئو كد كذلك على ضرورة تنوع المعلمين، وتنوع مناهجهم وطرق تدريسهم، وأتـــــ

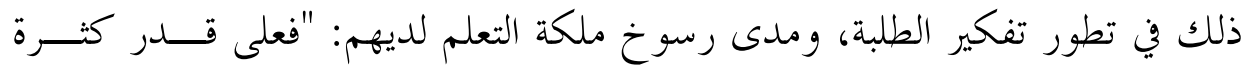
الشيوخ يكون حصول المَّكات ورسوخها... فلقاء أهل العلوم، وتعدد المشايخ، يفيده

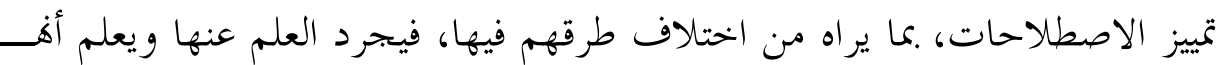
أنحاء تعليم، وطرق توصيل، وتنهض قو اه إلى الرسوخ والاستحكام في الملكات."(7 (1)

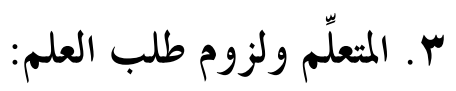
تحت عنوان "في أن الصنائع إنما تستجاد وتكثر إذا كثر طالبها" يشير ابن خلدون

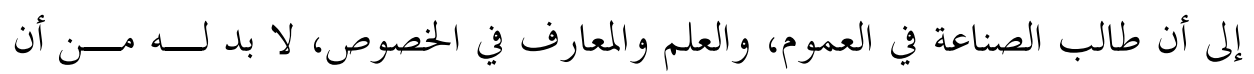

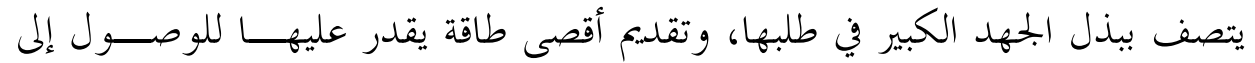
الهدف المرجوِّ. والسبب في ذلك ظاهرٌ كما يقول: "وهو أن الإنسان لا يسمح بعمله

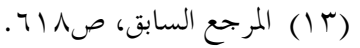

$$
\begin{aligned}
& \text { (ع () المرجع السابق، الصفحة نفسها. }
\end{aligned}
$$

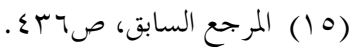

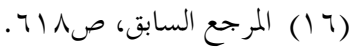


أن يقع بحاناً؛ لأنه كسبه ومنه معاشه؛ إذ لا فائدة له في جميع عمره في شيء مما سواه،

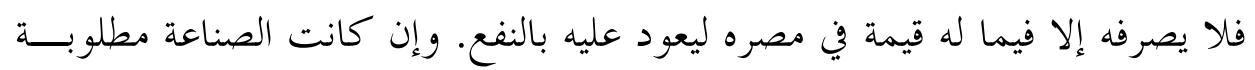

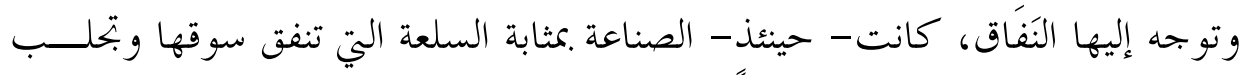
للبيع، فيجتهد الناس في المدينة لتعلُّم تلك الصناعة؛ ليكون منها معاشهم. وإذا لم تكن النه

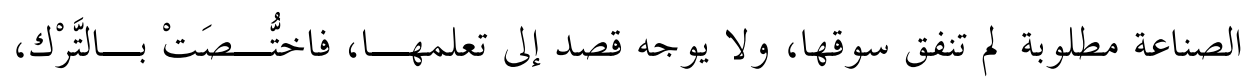

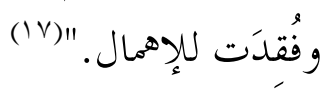

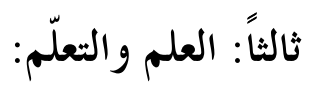

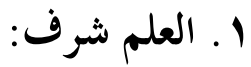

يتفق ابن خلدون مع الإمام أبي حامد الغزاليّ، في أن العلم صناعة شريفة راقية، لا كباقي الصناعات التي يمتهنها الإنسان. ويمثل على ذلك بحديثه حول الخط و الكتابــة عندما يصفهما بأفما من عداد الصنائع الإنسانية. وهي رسوم وأشكال حرفية تــــل على الكلمات المسموعة الدالة على ما في النفس. فهي ثاني رتبة عن الدلالة اللغويــة،

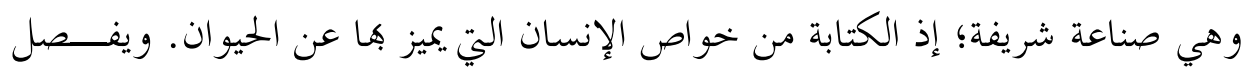

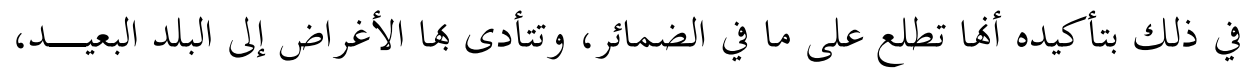

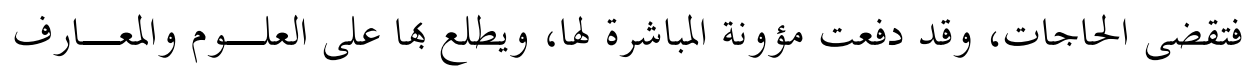

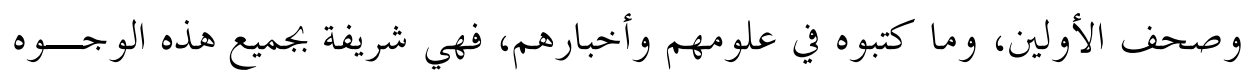
و المنافع. و خرووجها في الإنسان من القوة إلى الفعل إنما يكون بالتعليم. وعلــى قــــر

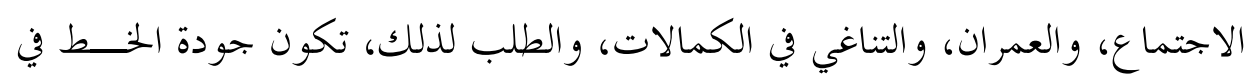

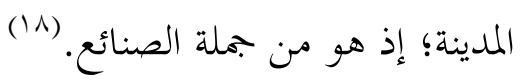




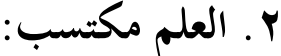

العلم عند ابن خلدون كله مكتسب بجهد البشر، لكن هذا الجهد لا بد أن يكون جهداً مستمراً كي تتحقق غاياته الكبرى. "وعِلم البشر هو حصول صورة المعلوم في

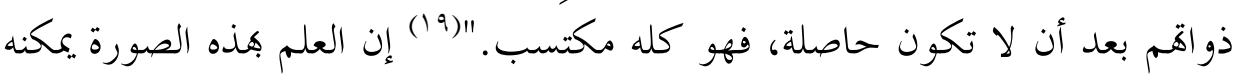

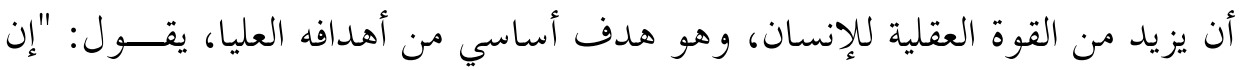
النفس الناطقة لإنسان، إنما توجد فيه بالقوة. وأن خرو جها من القوه القوة إلى الفعل إنما هو

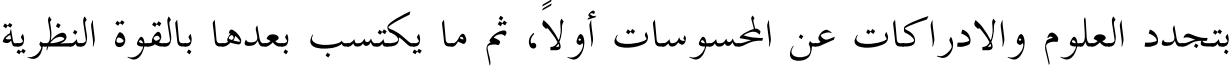

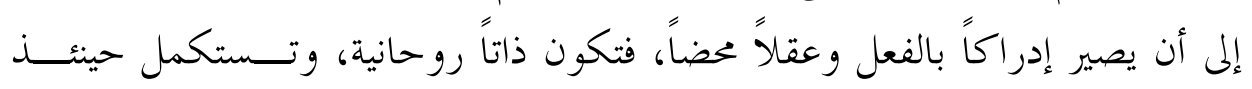
وجودها. فوجب لذلك أن يكون كل نوع من العلم و النظر يفيدها عقــلاً فريـــاً.

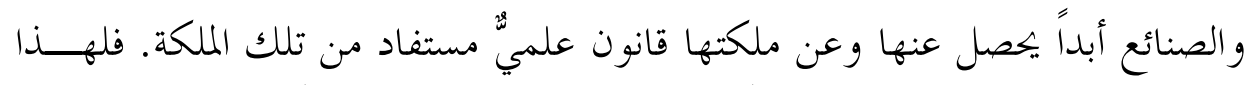
كانت الحنكة في التجربة تفيد عقلاً، والملكات الصناعية تفيد عقلاً، و الحضارة الكاملة تفيد عقلاً. "(r.)

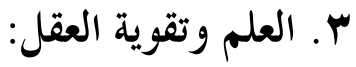

وفي مقام آخر، و حول أثر العلوم في قوة العقل، يأخذ الكتابة مثـــالاً مـــن بــــنـ

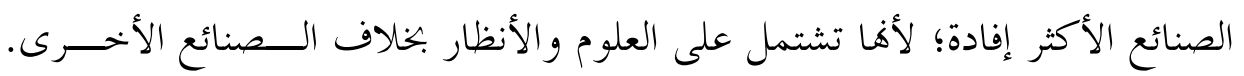

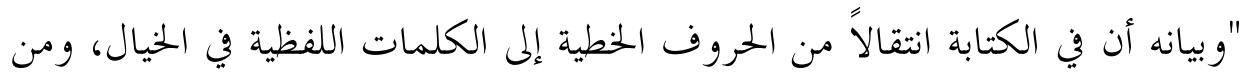
الكلمات اللفظية في الخيال إلى المعاني التي في النفس، فهو ينتقل أبداً من دليل إلى دليل،

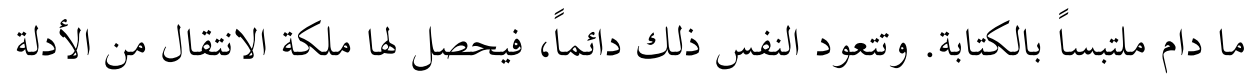

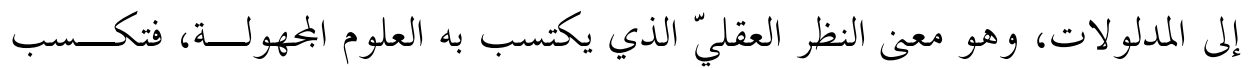
بذلك ملكة من التعقل تكون زيادة عقل، ويكصل به مزيد فطنة و كيْس في الأمور؛ لما لمابل

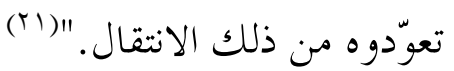

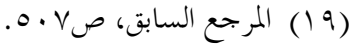

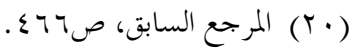

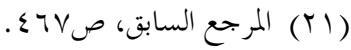


وفي السياق نفسه، يبيّن ابن خلدون أثر العلم في تقوية الذكاء عنــــ الإنــسان،

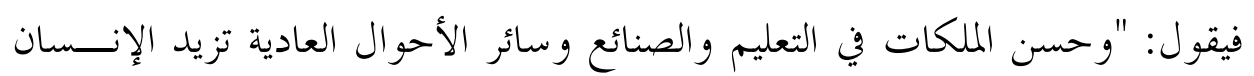

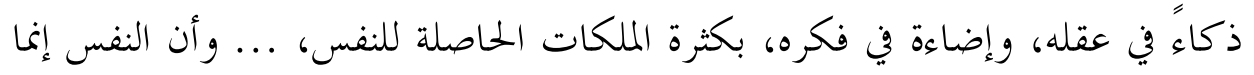

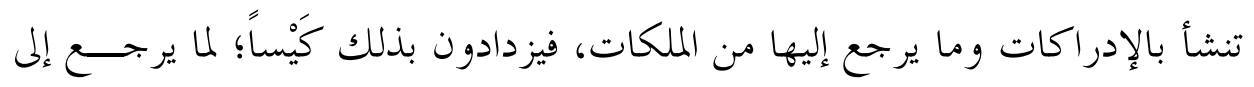

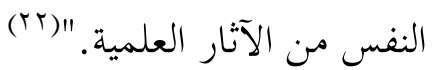

\section{ع ـ ـ العلم والحضارة:}

وفي موضوع من أكثر الموضوعات أهمية، يربط ابن خلدون بين العلم والحضارة

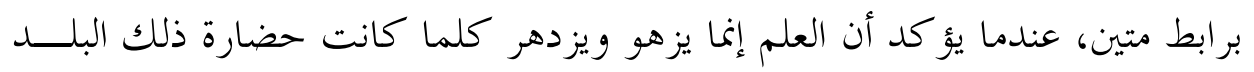

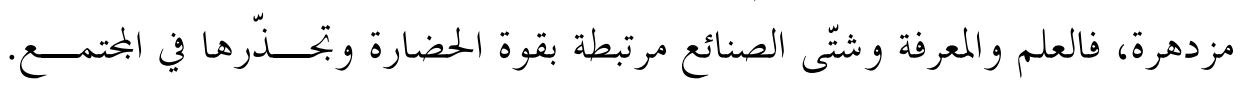

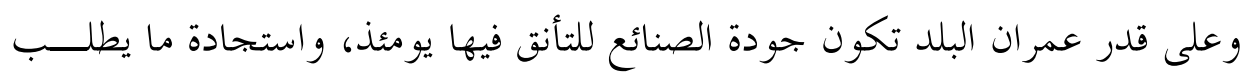

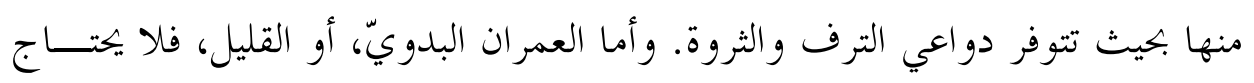

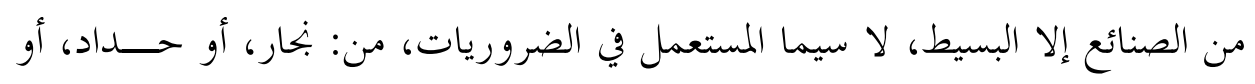

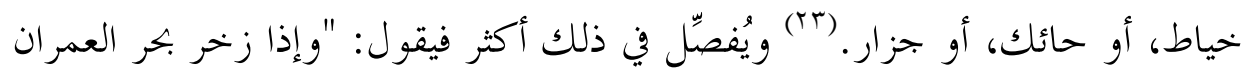

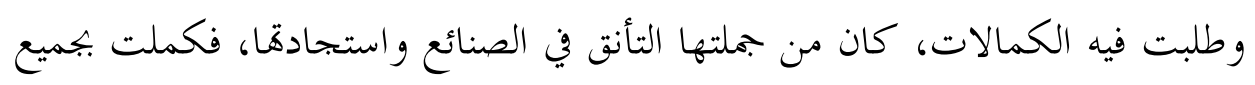

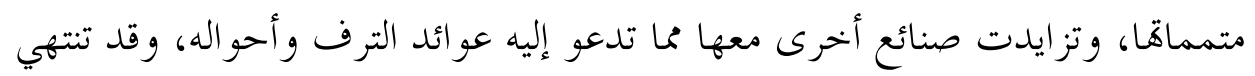

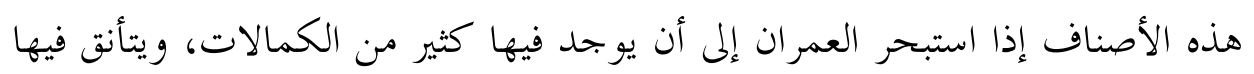

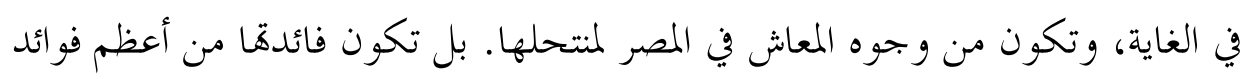

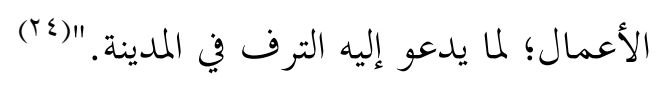

بل إن رسوخ الصنائع في الأمصار إنما هو برسوخ الحـــضارة وطـــــل أمــــهـا.

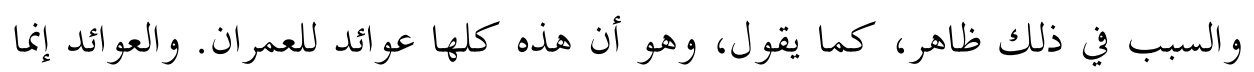

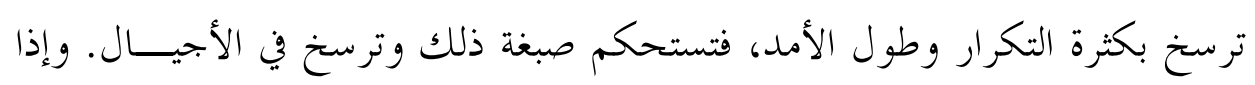


استحكمت الصبغة عسر نزعها. ولهذا فإنّا بجد في الأمصار التي كانت اســتبحرت في الحضارة، لما تراجع عمراها وتناقص، بقيت فيها آثار من هذه الصنائع ليست في غيرها

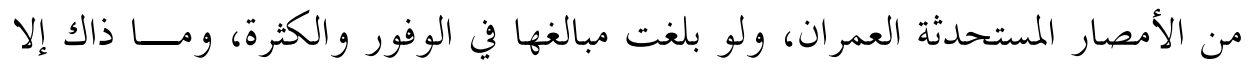
لأن أحوال تلك القديمة العمران مستحكمة راسخة بطول الأحقاب، وتداول الأحوال

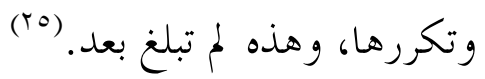

وحول موضوع العلوم تحديداً، فإن الرجل يؤ كد أها إنما تكثر حيث يكثر العمران و تعظم الحضارة. "إن تعليم العلم من جملة الصنائع، وأن الصنائع إنما تكثر في الأمصار. وعلى نسبة عمر اها في الكثرة والقلة والحضارة والترف، تكون نسبة الصنائع في الجهودة و الكثرة؛ لأنه أمر زائد على المعاث. فمتى فضلت أعمال أهل العمران عن معاشـــمه،

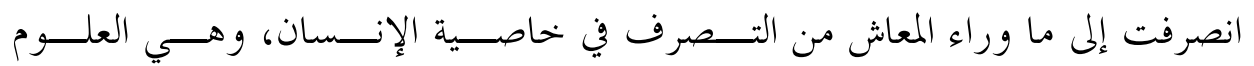

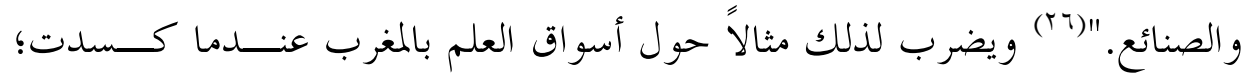

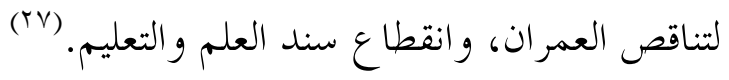

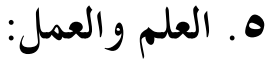

إن العلم عند ابن خلدون مرتبط ارتباطاً وثيقاً بالعمل و الحياة التطبيقية، "و العلـــم الحاصل عن الاتصاف ضرورة، هو أوثق مبنى من العلم الحاصل قبل الاتصاف. وليس الاتصاف بحاصل عن بجرد العلم، حتى يقع العمل ويتكرر مراراً غير منحصرة، فترسخ

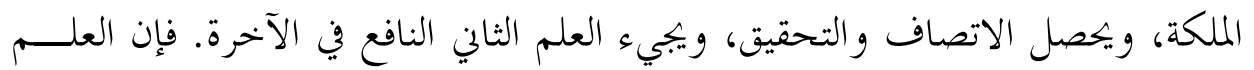

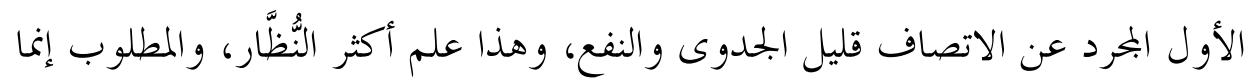

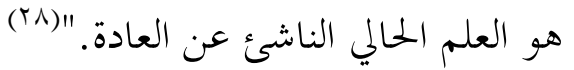

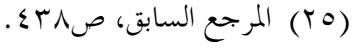

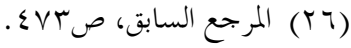

$$
\begin{aligned}
& \text {. المرجع السابق، صن (YV) }
\end{aligned}
$$

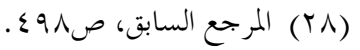




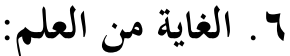

أما الغاية العظمى من العلم عند ابن خلدون، فتتمثل في تعميق التوحيد والإيمـــان

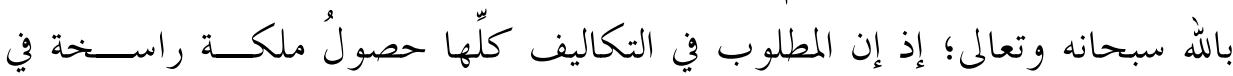

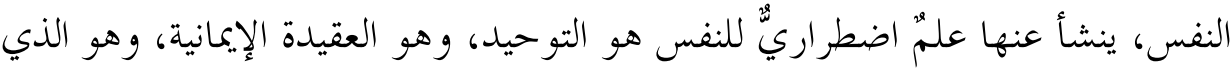

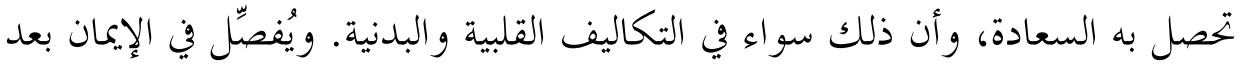

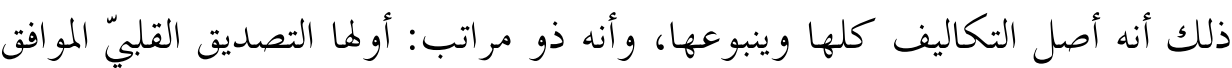

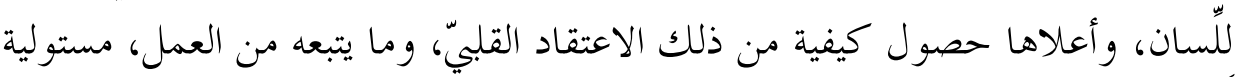

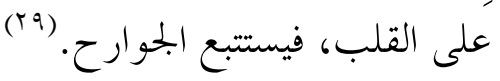

\section{V. ضرورة التخصص في العلم:}

يؤ كد ابن خلدون على قضية هامة تتعلق بضرورة التخصص في العلـــم، وعـــــم

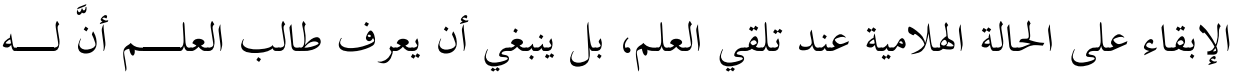

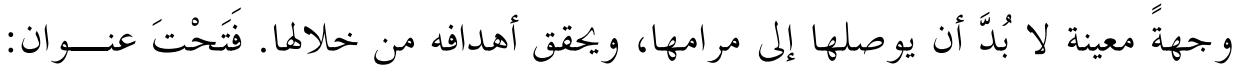

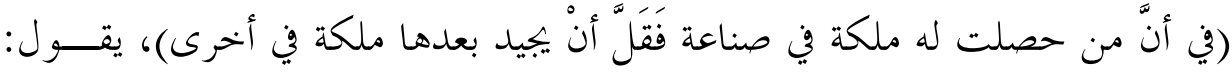

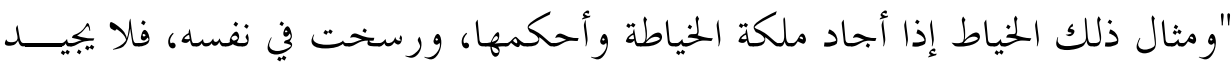

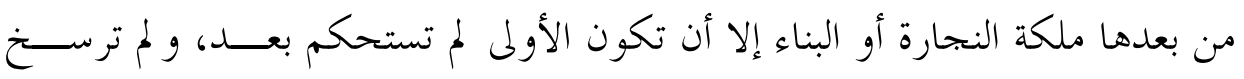
صبغتها. و السبب في ذلك، أن الملكات صفات للنفس وألوان، فلا تزدحم دفعة، ومن

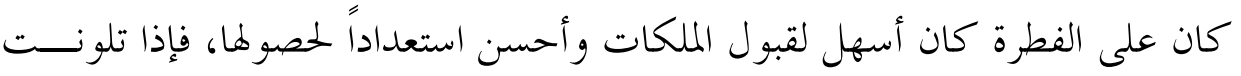
النفس بالملكة الأخرى، وخرجت عن الفطرة ضعف فيها الاستعداد باللون الحاصل من

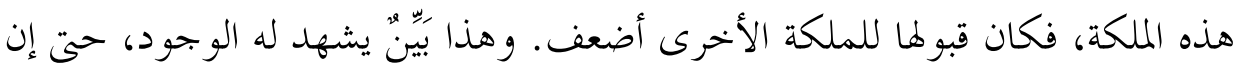

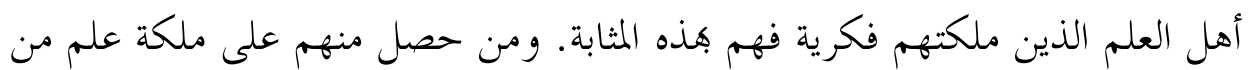

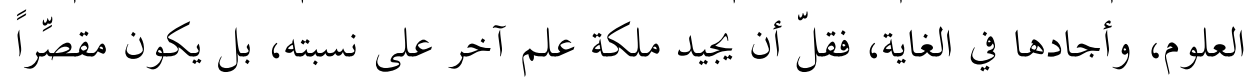

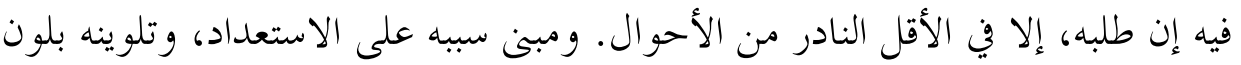

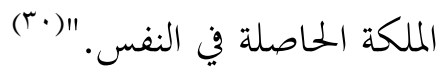


ويحث ابن خلدون المعلمّم على بعض المذاهب الجميلة والطرق الواجبة في التعليم،

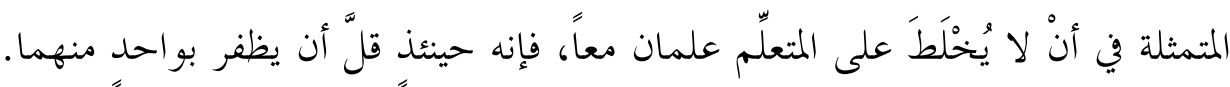
ويوضح ذلك بأنَّ في هذا النهج تقسيم البال وانصر افه عن كل واحد منهما إلى تفهم

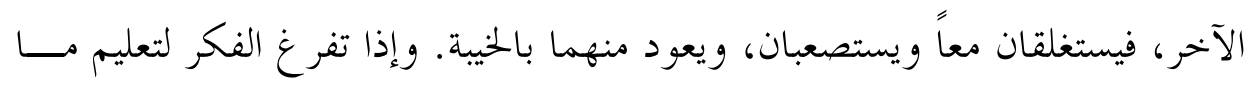

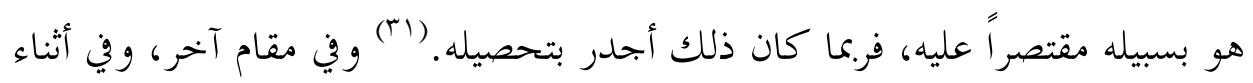

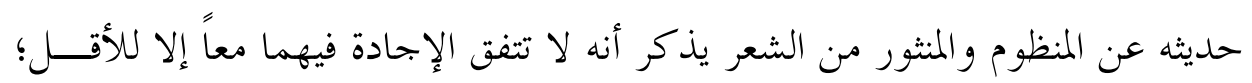

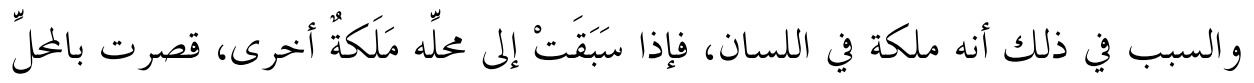

عن تمام الملكة اللاحقة.

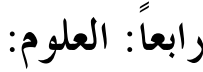

\section{ا ـ العلوم ضرورية وشريفة:}

يقسم ابن خلدون العلوم بشكل عامٍٍ إلى: ضروريّ وشريف. ويذكر أنَّ الصنائع

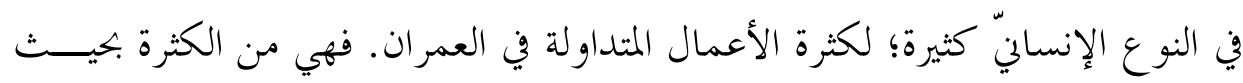

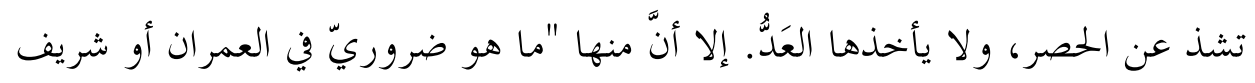
في الموضوع، فنخصها في الذكر ونترك ما سواها: فأما الضروريّ، فكالفلاحة، والبناء،

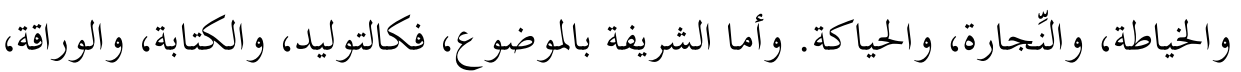

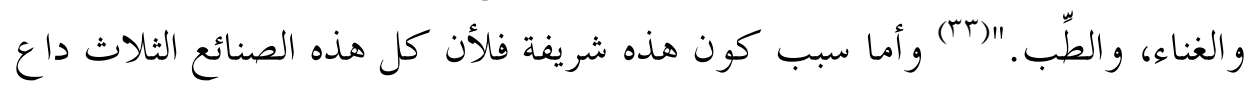

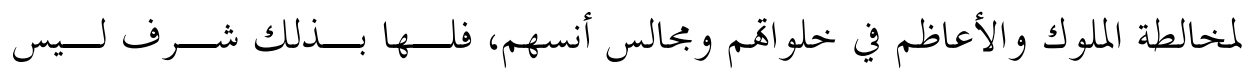
لغيرها. (r) 


\section{r r أصناف العلوم الو اقعة في العمران:}

يقسم ابن خلدون العلوم من حيث وسيلة الحصول عليها إلى نــــوعين: طبيعـيّ

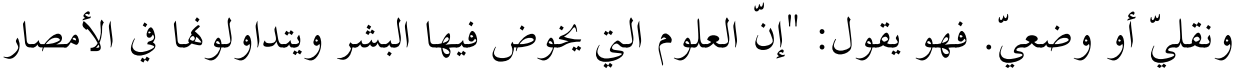

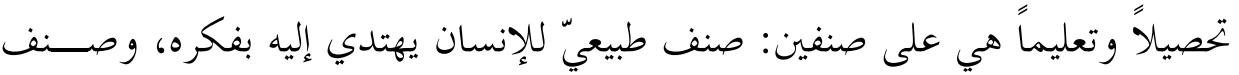

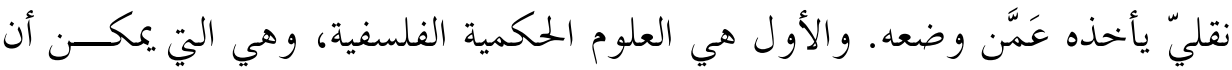

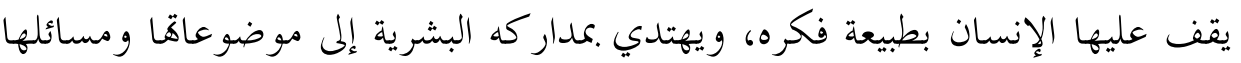
وأنحاء براهينها ووجوه تعليمها، حتى يقفه نظره وبحثه على الصواب من الخطأ فيها فيها،

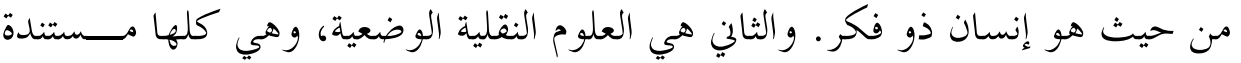

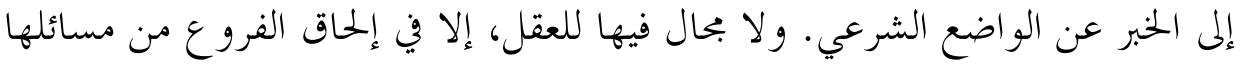

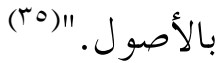

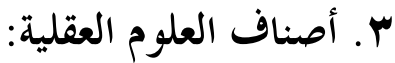

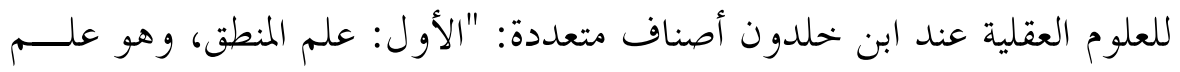

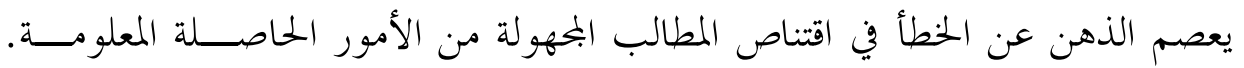

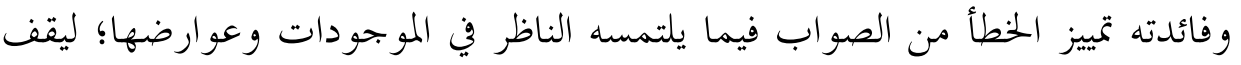

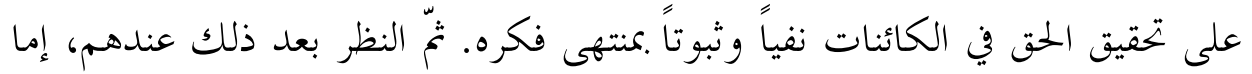

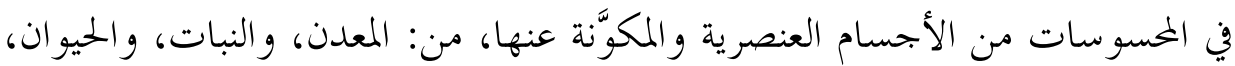

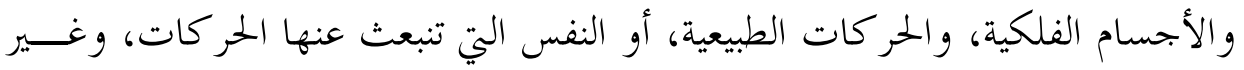

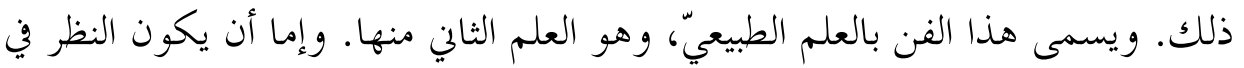

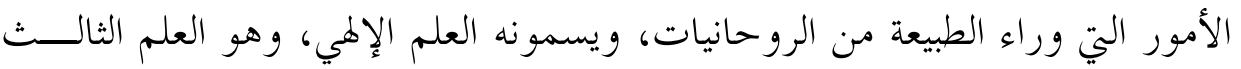

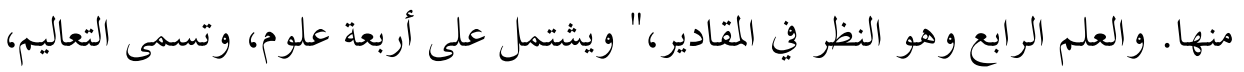

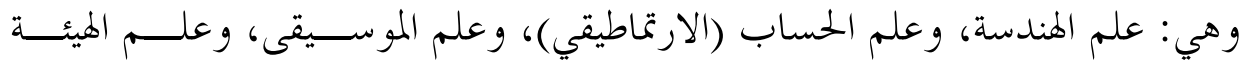

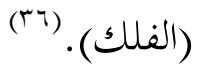

$$
\begin{aligned}
& \text { المرجع السابق، صع لعـ. }
\end{aligned}
$$

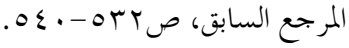




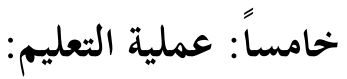

\section{1 ـ التعليم صناعة من الصناعات:}

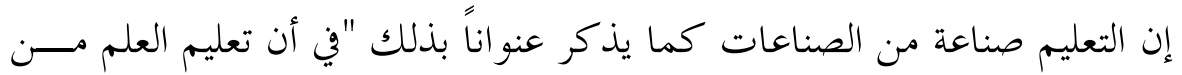

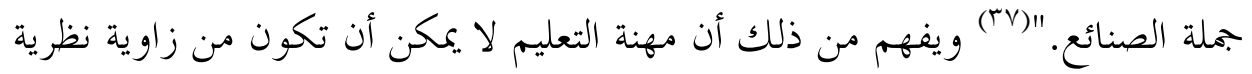

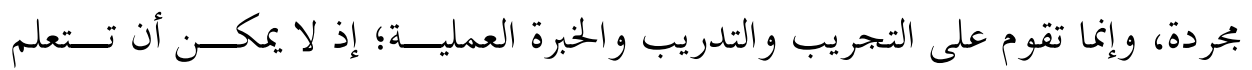

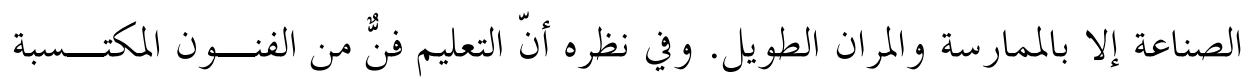

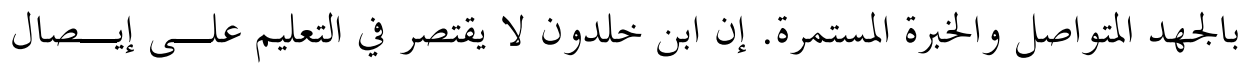

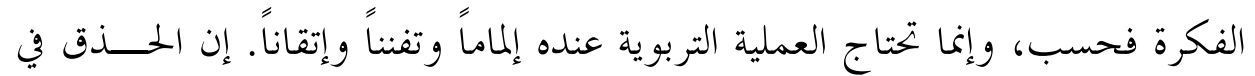

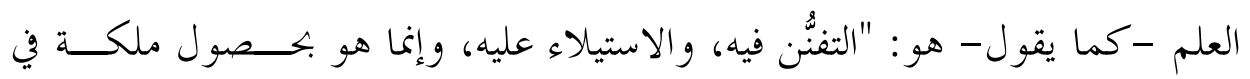

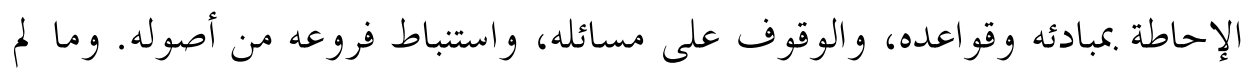

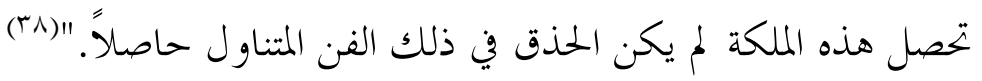

\section{Y. منهجية التعليم:}

ولتلتعليم منهجية علمية موضوعية عند ابن خحلدون. فعلى من يمارس عملية التعليم

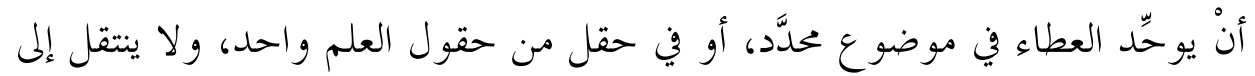

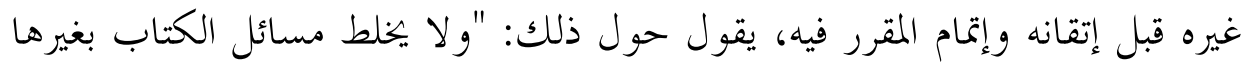

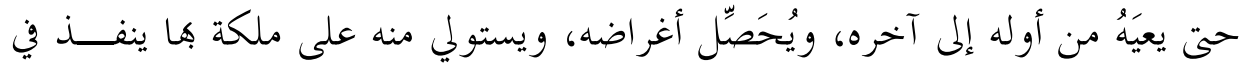

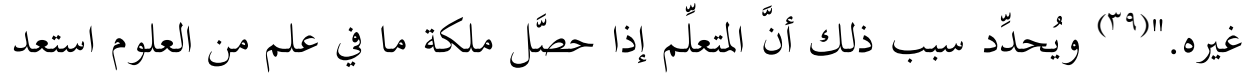

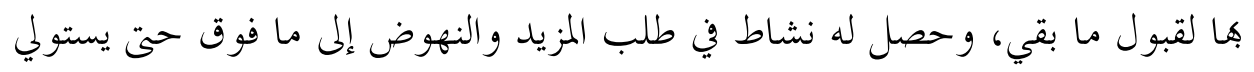

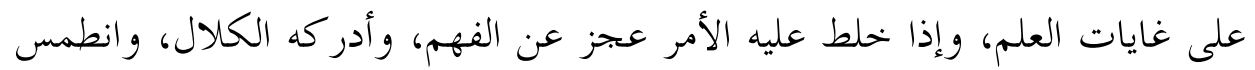

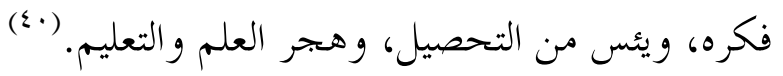

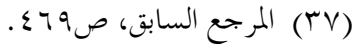

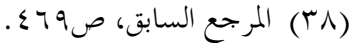

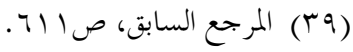

$$
\begin{aligned}
& \text { (•) المرجع السابق، الصفحة نفسها. }
\end{aligned}
$$




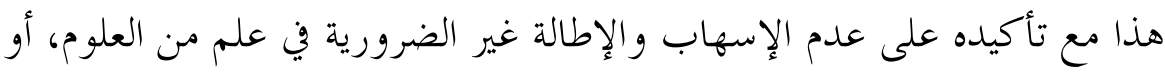

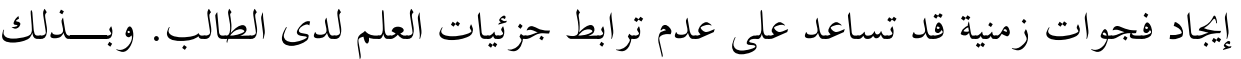

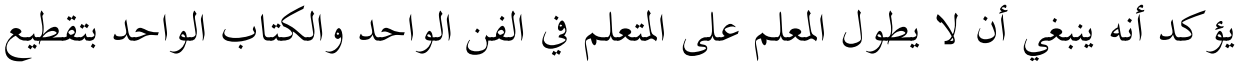

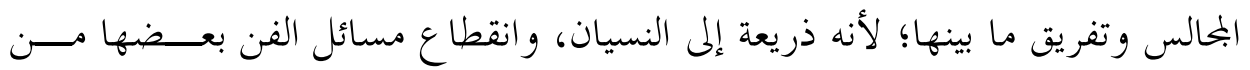

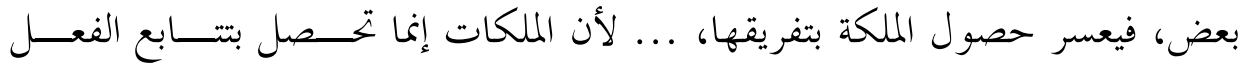

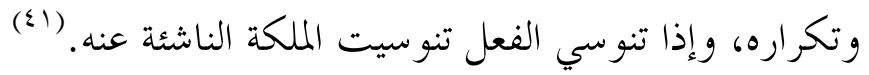

\section{r. التطبيقات التربوية والممارسات التعليمية:}

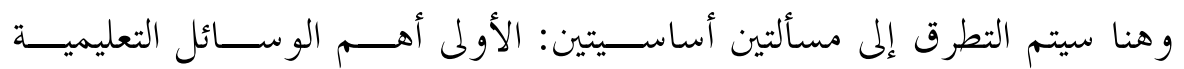

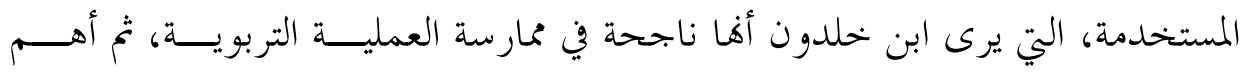

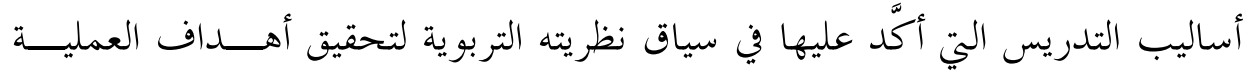

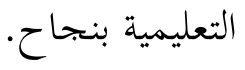
إن أنجع الطرق والوسائل التعليمية عند ابن خحلدون، هي ما كانت من لقاء العلماء

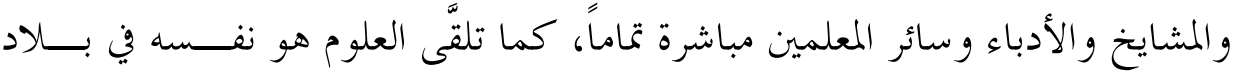

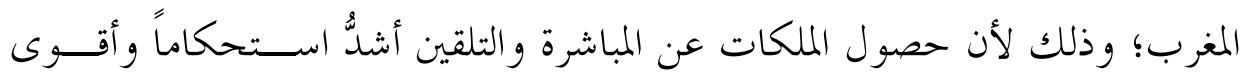

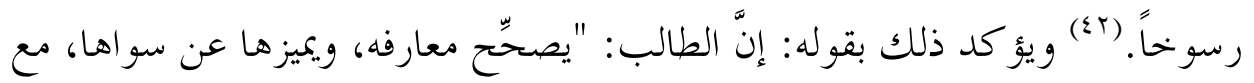

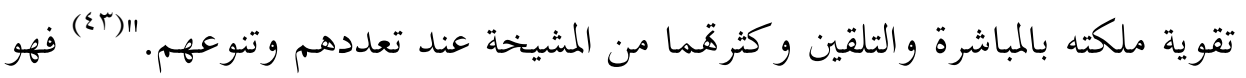

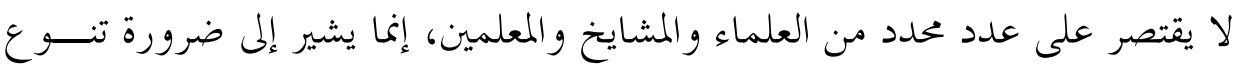

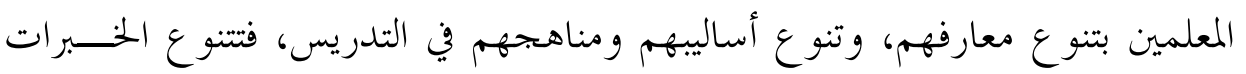

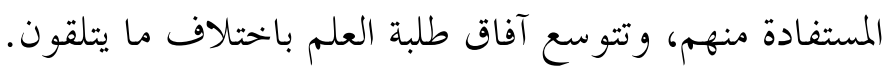

والرحلة ضرورية عند ابن خلدون بوصفها وسيلة من وسائل كسب العلــــ؛ إذ

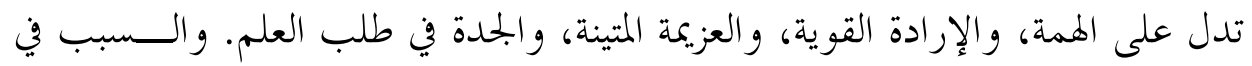

$$
\begin{aligned}
& \text { عالمرجع السابق، الصفحة نفسها. }
\end{aligned}
$$

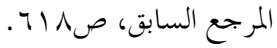

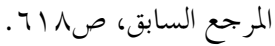


ذلك - كما يقول: إن البشر يأخذون معارفهم وأخلاقهم وما ينتحلونه من المـــذاهب

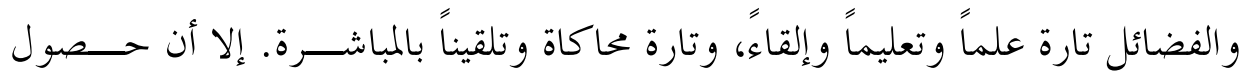

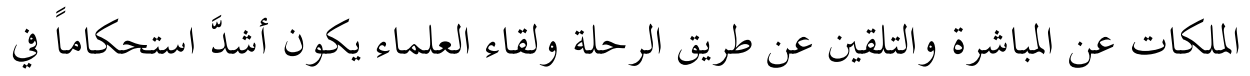

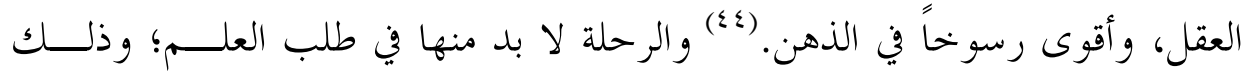

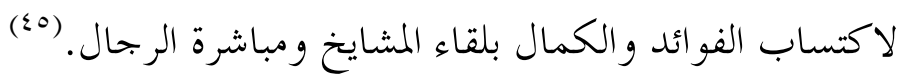

إن من أهم أساليب التدريس عند ابن خلدون، التلقين المباشر بين المعلم والمتعلِّم؛

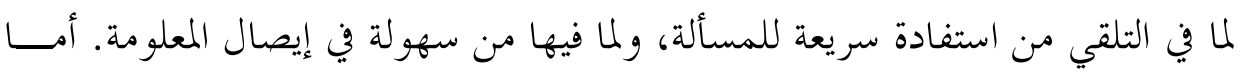

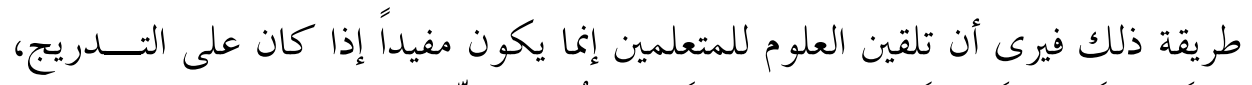

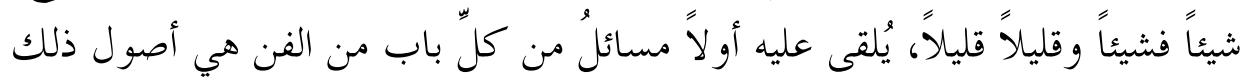

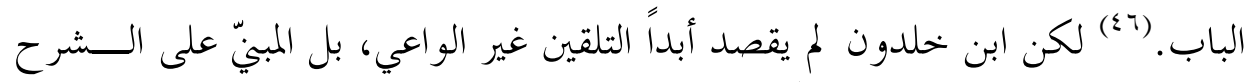

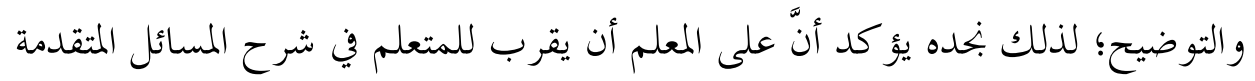
الذكر على سبيل الإجمال، بل ويراعى في ذلك قوة عقله، و استعداده لقبول ما يــورد عليه، حتى ينتهي إلى آخر الفن، وعند ذلك يكصل له ملكة في ذلك العلم. (گV) بل يؤ كد مرة أخرى على ضرورة أن لا يُتركك الطالب دون توضيح وشـــــ إلى

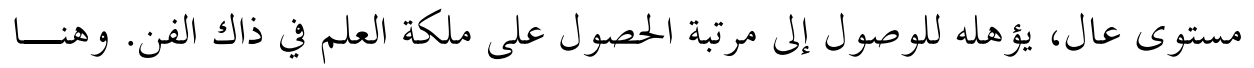

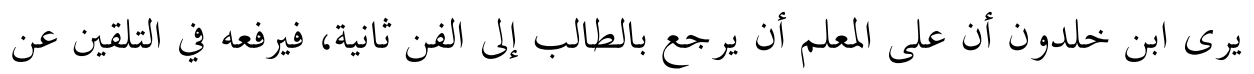

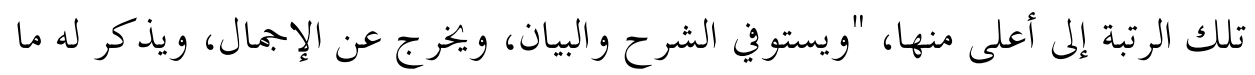

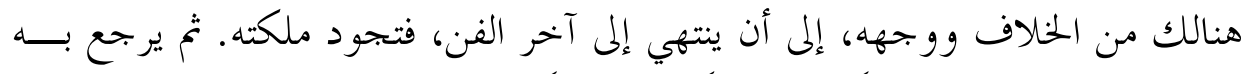

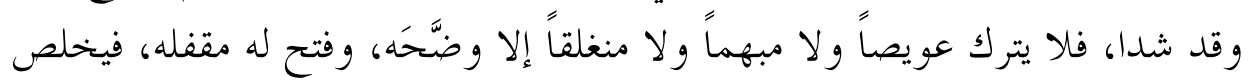

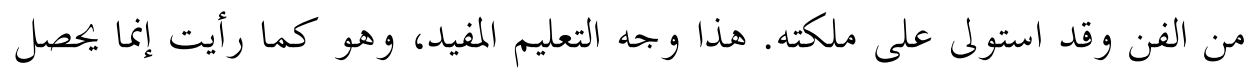

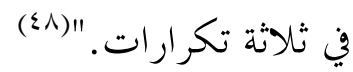


لكن ابن خلدون لم يقتصر على هذا الأسلوب من أساليب التدريس، بل ركــز على أهمية المحاورة والمناظرة والمفاوضة، وعدم الاقتصار على عملية التلقين في الشرح، يقول في هذا المقام: "وأيسر طرق هذه الملكة فتق اللسان بالمحاورة والمناظرة في المسائل العلمية، فهو الذي يقرِب شأفا، ويحصِّل مرامها، فتجد طالب العلم منهم بعد إمد ذهاب

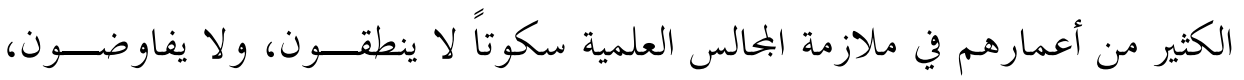

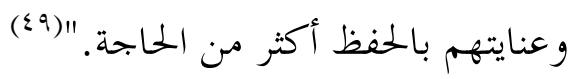

وهو لا يُقَلِّل من شأن الحفظ، فإنّ من المفيد الإكثار من الحفظ في المتون العربية؛

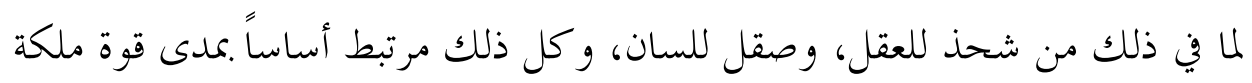
علم الطالب، وبذلك فإنه "لا بد من كثرة الحفظ، لمن يروم تعلم اللسان العربي، وعلى

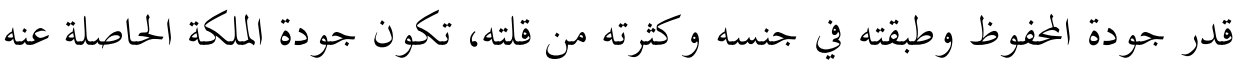

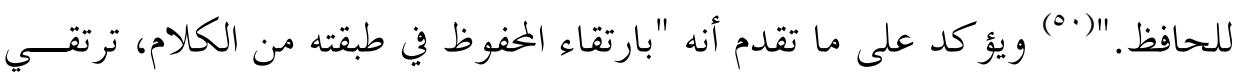

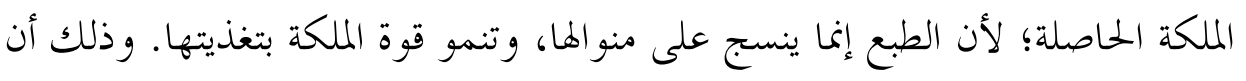
النفس، وإن كانت في جبلتها واحدة بالنوع، فهي تختلف في البشر بالقوة والضعف في (الإدراكات." (1) (1)

ويرى ابن خلدون ضرورة التدرج في إيصال العلم إلى مختلف الطلبة؛ لما لذلك من أثز كبير في ترسيخ المعارف، لا سيما تلك التي تحتاج إلى مهارة وفن وصناعة، يقول: إلى

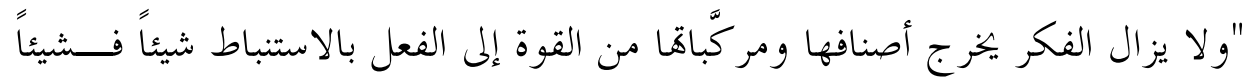

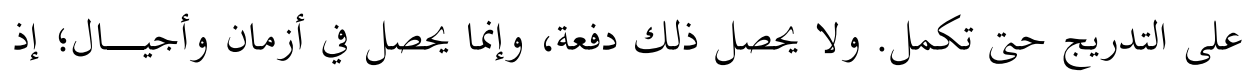
خروج الأشياء من القوة إلى الفعل لا يكون دفعة، لا سيما في الأمور الصناعية، فلا بدَّ ولئ

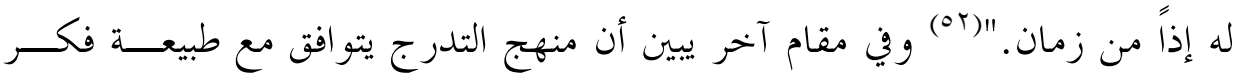

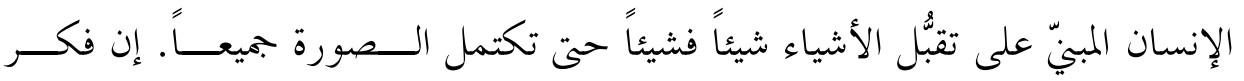

$$
\begin{aligned}
& \text { المرجع السابق، صبr؟ }
\end{aligned}
$$

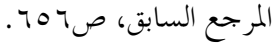

$$
\begin{aligned}
& \text { المرجع السابق، الصفحة نفسها. }
\end{aligned}
$$

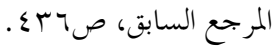


الإنسان ونظره: "يتوجه إلى واحد من الحقائق، وينظر ما يعرض له لذاته و احداً بعــــ آخر، ويتمرن على ذلك حتى يصير إلحاق العوارض بتلك الحقيقة ملكة له، فيكــــون

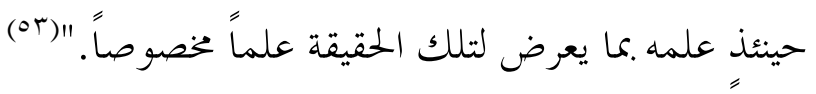
وعلى الرغم مما تقدم، فإنّ ابن خلدون يرى أن تعلم بعض العلوم يكون أبخع إذا

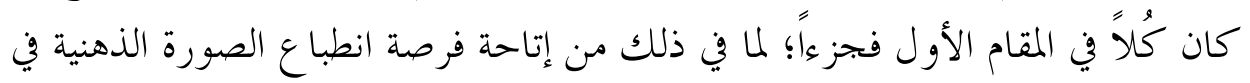

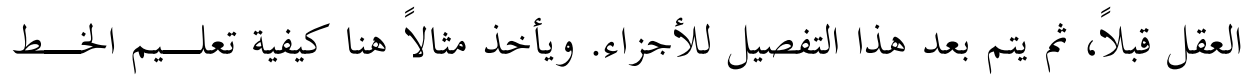
بالأندلس والمغرب، في أنه لا يتم بتعليم كل حرف بانفر اده، على قوانين يلقيها المعلم للمتعلم، "و إنما يتعلم .محاكاة الخطط من كتابة الكلمات جملة. ويكون ذلك من المتعلم

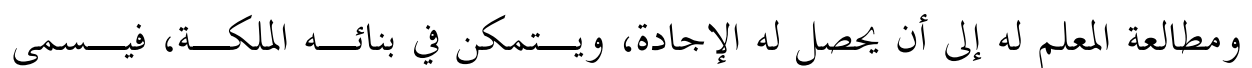

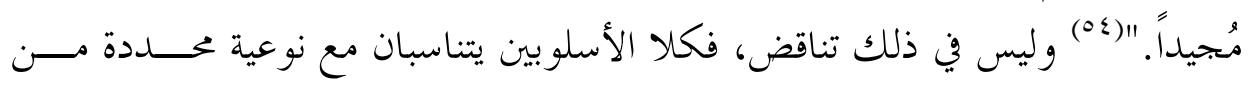
مختلف العلوم بطبيعة مفرداها و محتو اهـا.

وفي سياق مشابه يرى أن التعليم ينبغي أن يكون فيه يسر في الطرح، ويسـسر في

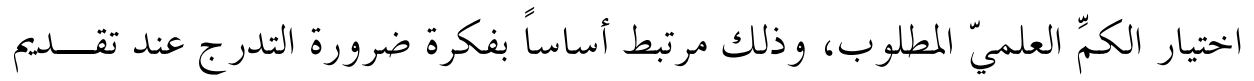
العلم للطلبة، يقول في ذلك: "ولو اقتصر المعلمون بالمتعلمين على المسائل المذهبية فقط

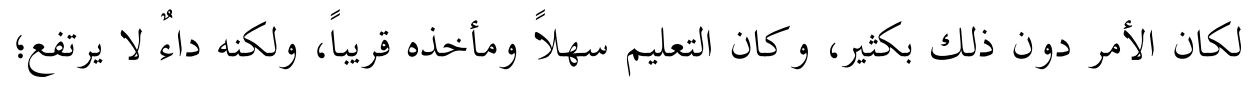

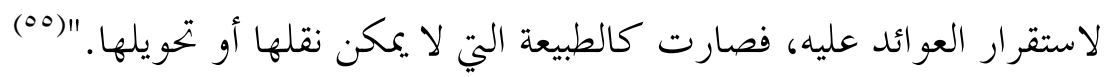
وعند شرح مختلف المسائل للمتعلم يرى ابن خلدون ضرورة مراعاة طاقة المتعلم، وطبيعة استعداداته المختلفة؛ كي يقع العلم على من يطلبه بالقدر الذي يحتمله؛ لذلك نراه يؤ كد أنه ينبغي أن: "يراعى في ذلك قوة عقله واستعداده لقبول ما يورد عليــه،

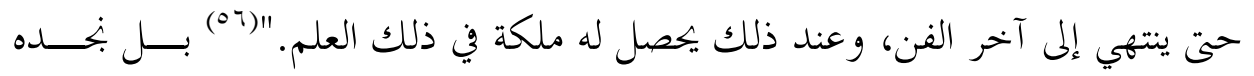

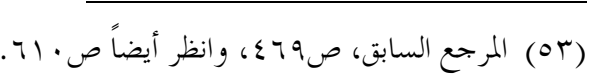

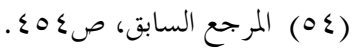

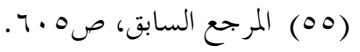

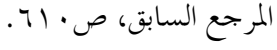




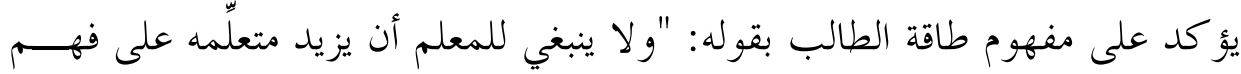

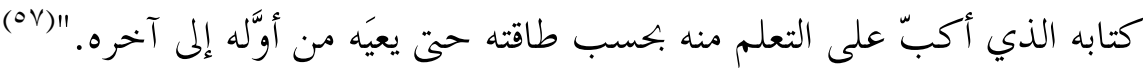

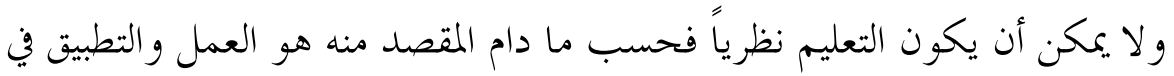

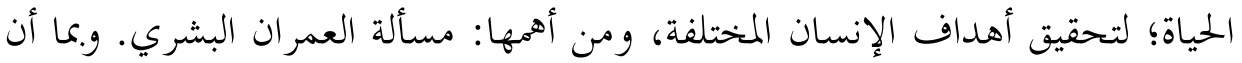

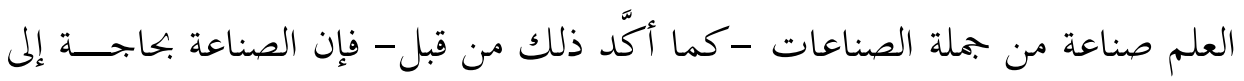

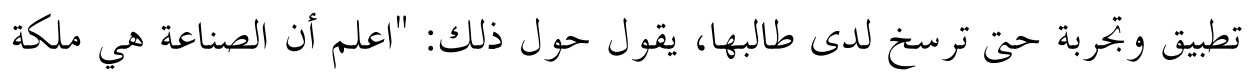

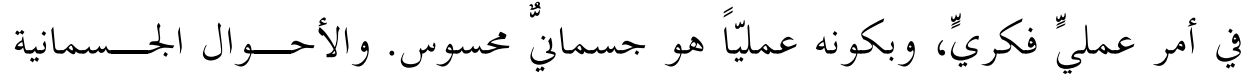

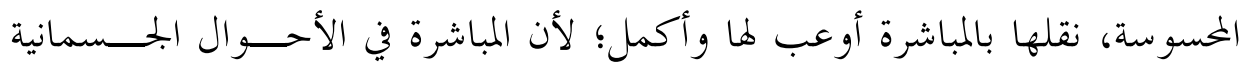

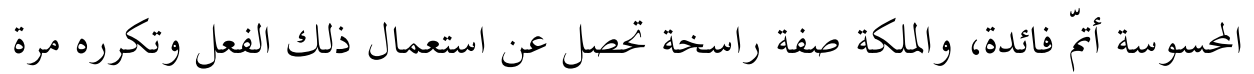

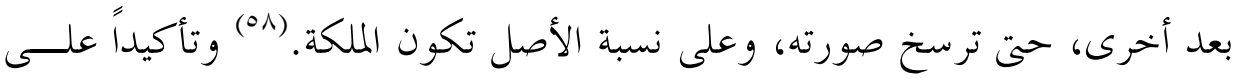

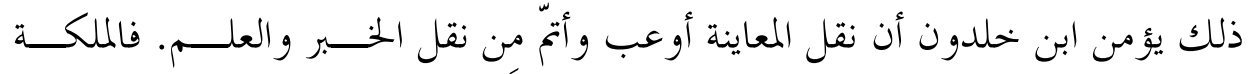

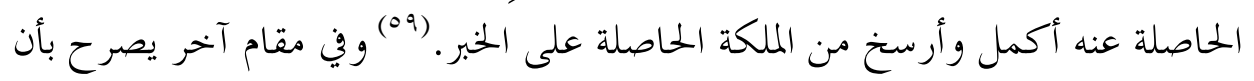

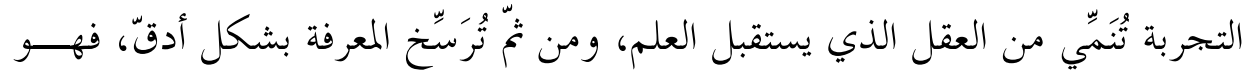

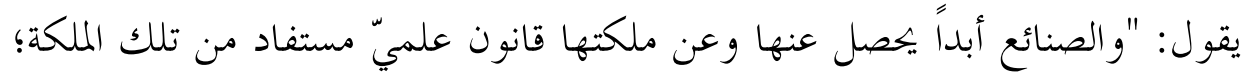

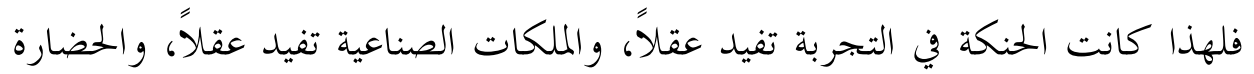

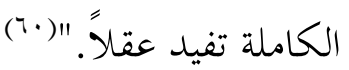

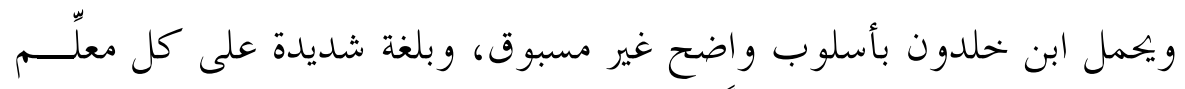

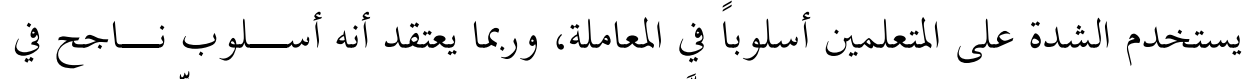

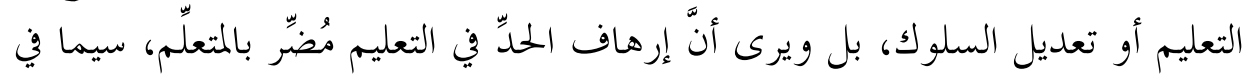

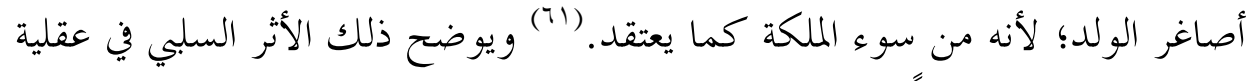

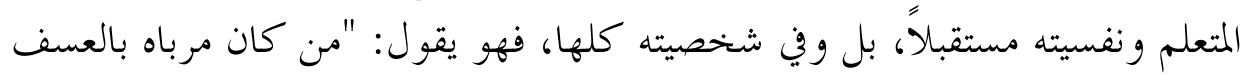

(or)

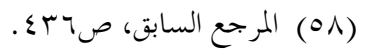

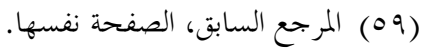

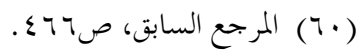

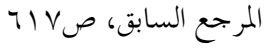




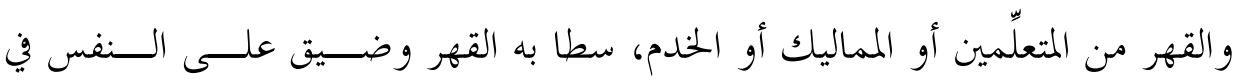

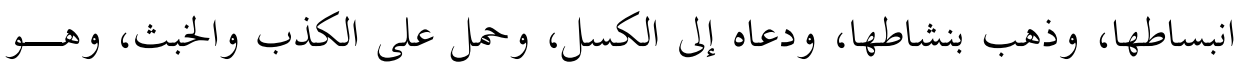

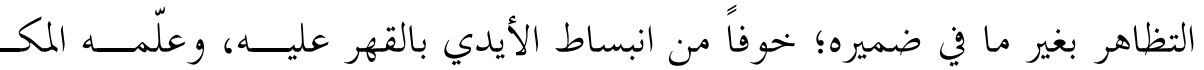

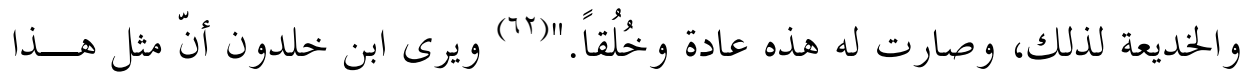

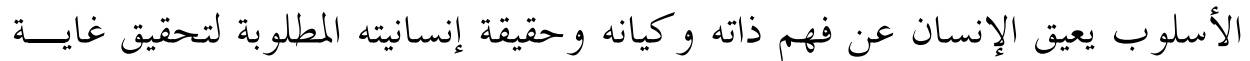

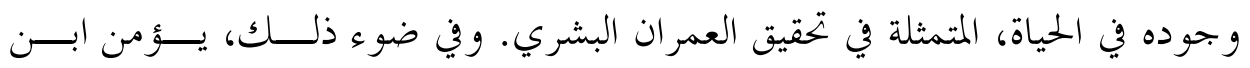

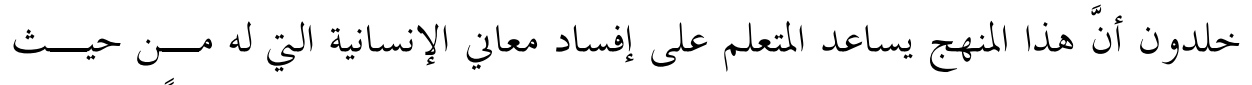

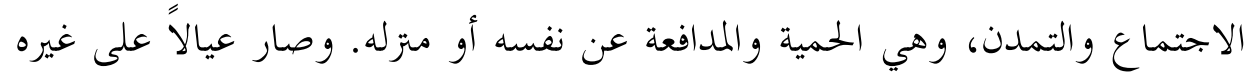

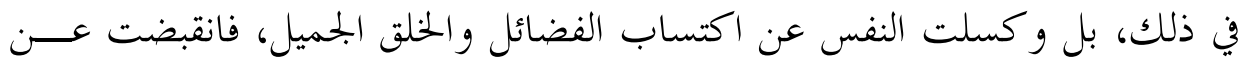

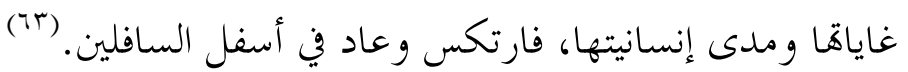

سادساً: المنهاج: الأهداف، والغتوى، واللغة المعتمدة:

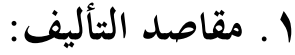

يجدد ابن خلدون أن المناهج التعليمية لا بد لها من غايات واضحة لدى واضعيها،

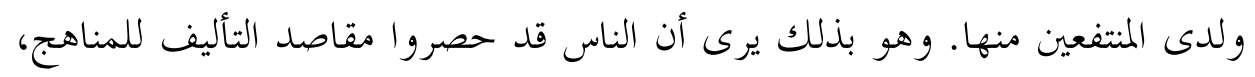
التي ينبي اعتمادها، بل وإلغاء ما سواها، في سبع غايات: أولها: استنباط العلم بموضوعه، وتقسيم أبوابه وفصوله، وتتبُع مسائله، أو استنباط

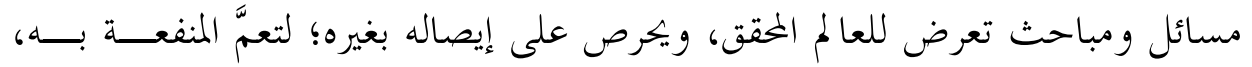
فيودع ذلك بالكتاب في المصحف، لعل المتأخر يظهر على تلك علك الفيائدة.

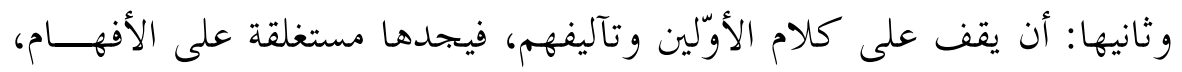

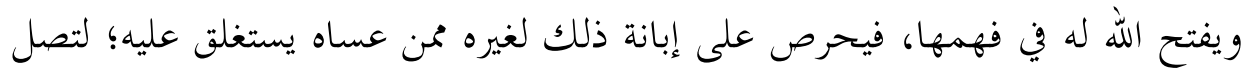
الفائدة إلى مستحقها. 
و ثالثها: أن يعثر المتأخر على غلط أو خطأ في كلام المتقدمين، ممن اشتُهر فضله، و بَعُد في الإفادة صيته، و يستوثق في ذلك بالبرهان الواضح الذي لا مدخل للشك فيه، فيحرص على إيصال ذلك لمن بعده.

ورابعها: أن يكون الفنُّ الواحد قد نقصت منه مسائل أو فصول، بحسب انقسام موضوعه، فيقصد المطلع على ذلك أن يتمم ما نقص من تلك المسائل؛ ليكمل الفــنـ

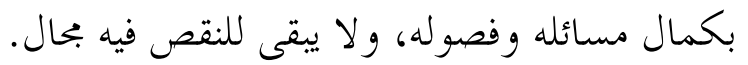

و خحامسها: أن تكون مسائل العلم قد وقعت غير مرتبة في أبو اهـا و لا منتظمــة، فيقصد المطلع على ذلك أن يرتبها ويهذها، ويجعل كل مسألة في باهـا. و سادسها: أن تكون مسائل العلم مفرقة في أبواها من علوم أخرى، فيتبه بعض الفضلاء إلى موضوع ذلك الفن وجميع مسائله، فيفعل ذلك، ويظهر به فن ينظمسـهـ في جملة العلوم التي ينتحلها البشر بأفكارهم.

وسابعها: أن يكون الشيء من التآليف التي هي أمهات للفنون مطولاً مــسهـباً،

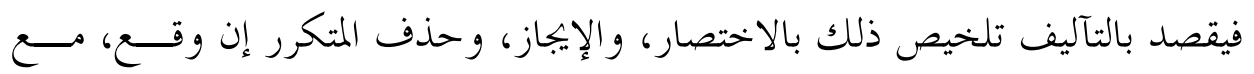

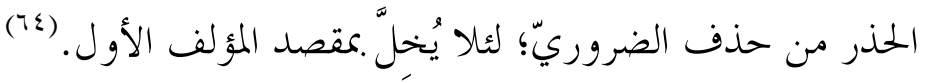

\section{Y. كثرة التآليف في العلوم عائقة عن التحصيل:}

يؤمن ابن خلدون أن المناهج ليست غاية في حد ذاتها، بل هي وســـيلة لتحقيــق

الغايات التعليمية المتمثلة بالفهم الدقيق لتفصيلات غختلف المعارف و العلوم، و العمـــل معتضاها؛ لذلك لا يرى ضرورة للإكثار من المؤلفات في العلم الواحد، إلا إذا اقتضت

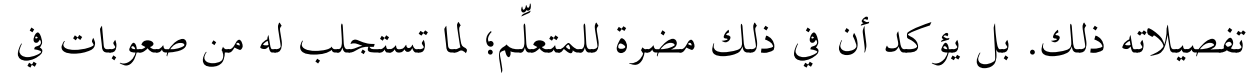

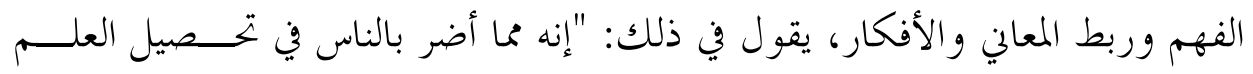
و الوقوف على غاياته، كثرة التآليف واختلاف الاصطلاحات في التعلــيم، وتعـــد طرقها، ثم مطالبة المتعلم و التلميذ باستحضار ذلك، و حينئذ يسلم له منصب التحصيل، 
فيحتاج المتعلم إلى حفظها كلّها، أو أكثرها، ومراعاة طرقها."(10) ويسوّغ ذلك أنه لا

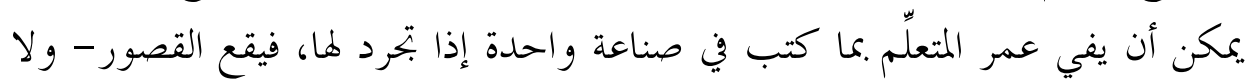

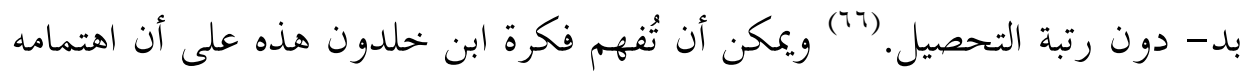

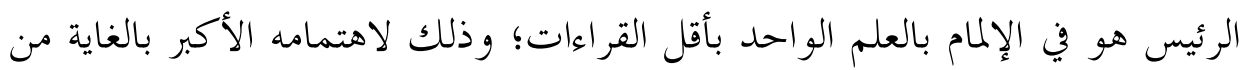

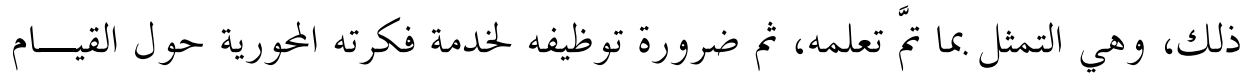
كمهمة العمر ان البشريّ، بوصفها غاية عظمى للحياة الإنسانية.

\section{r. كثرة الاختصارات الموضوعة في العلوم مخلة بالتعليم:}

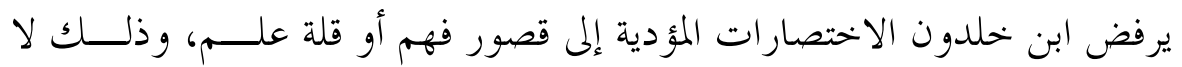

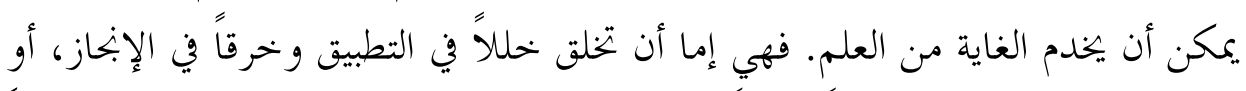

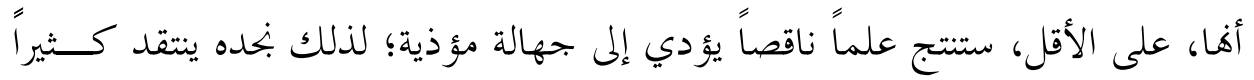

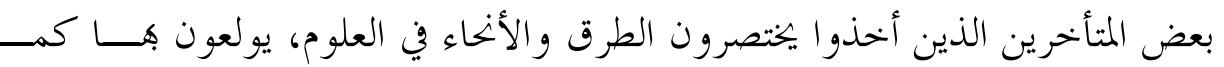

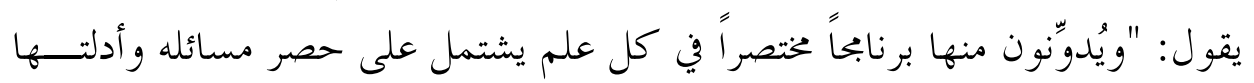

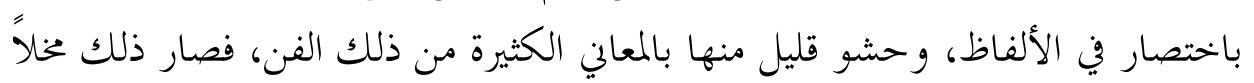

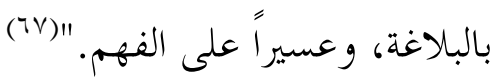

\section{ع ـ العلم والقر آن بوصفهما منهجين:}

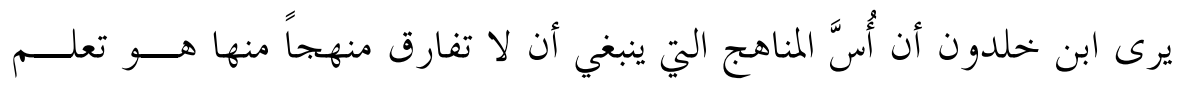

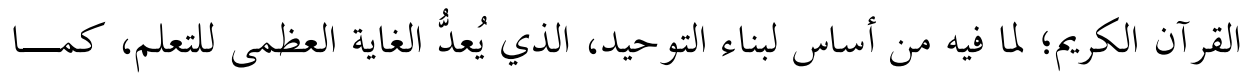

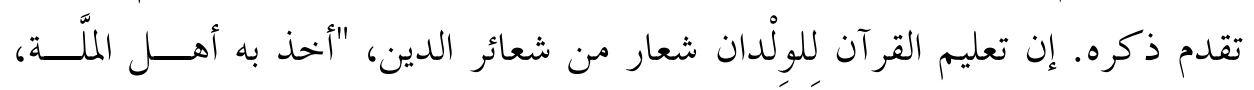

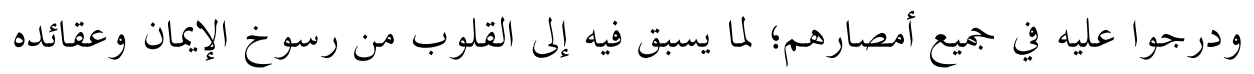

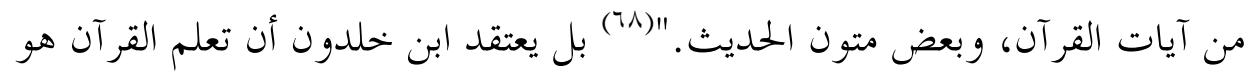

$$
\begin{aligned}
& \text { (70) المرجع السابق، ص0 •7.7. }
\end{aligned}
$$

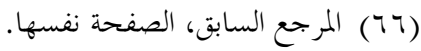

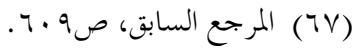

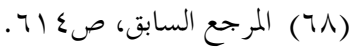


أساس بناء ملكات العلم كلها؛ لذلك يرى أن القرآن "صار أصل التعليم الذي ينسبني

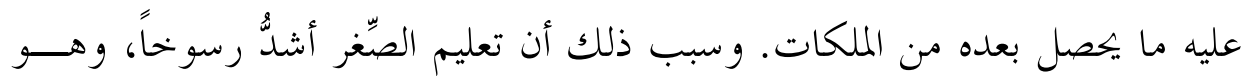

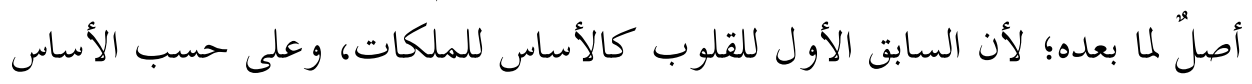

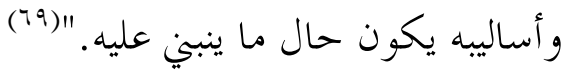

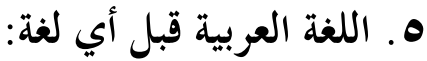

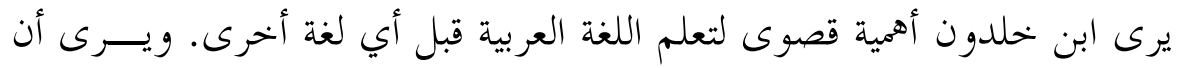

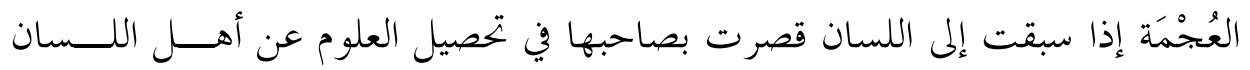

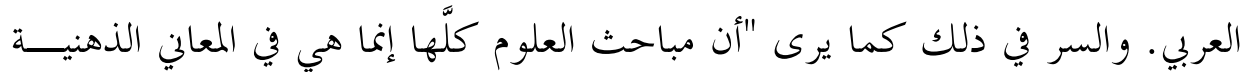

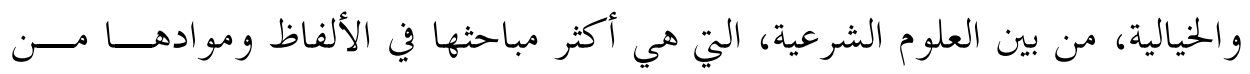

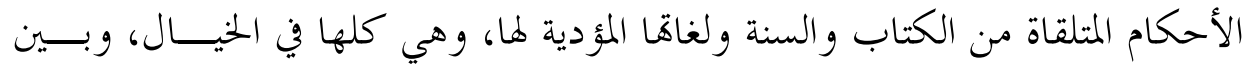

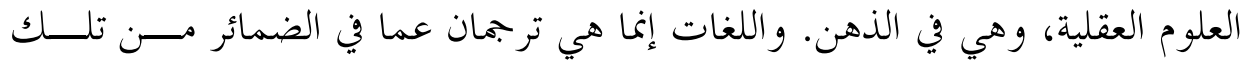

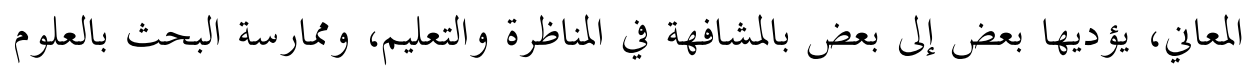

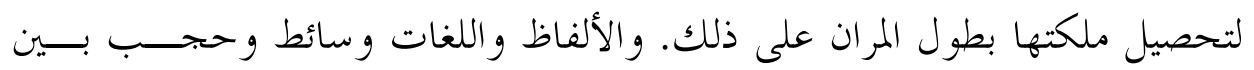
الضمائر، وروابط وختام عن المعاني. و لا بد في اقتناص تلك المعاني من ألفاظها لمعرفة

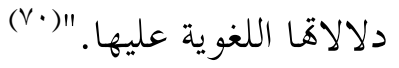

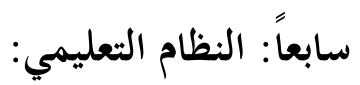

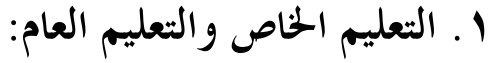

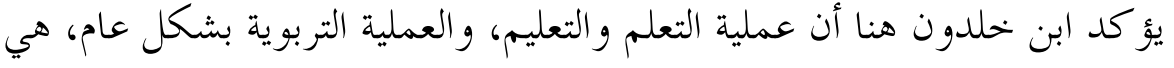

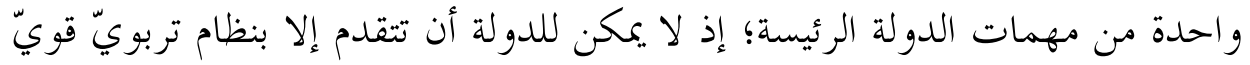

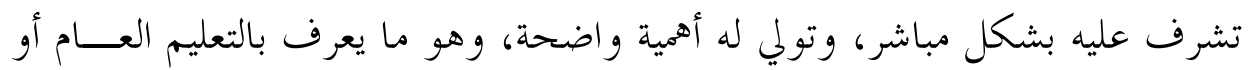


الرسميّ. وربما لا يلغي ذلك دور المؤسسات الخاصة للتعليم، ولكنه يؤكد على الدور

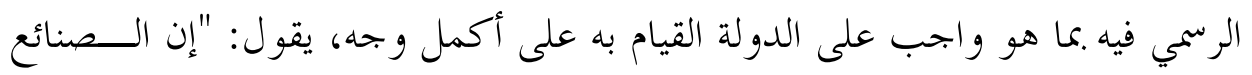

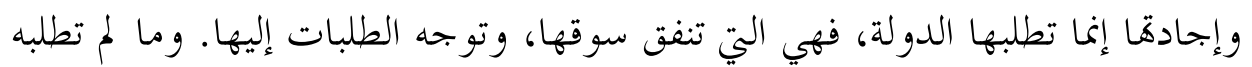

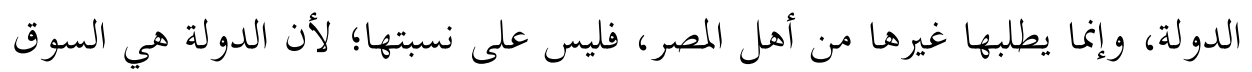

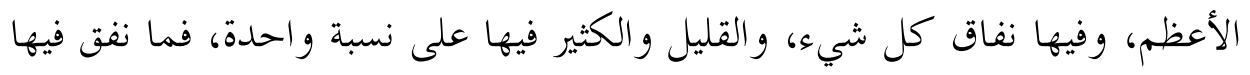

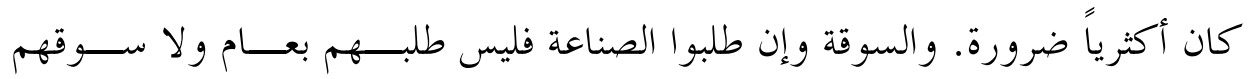

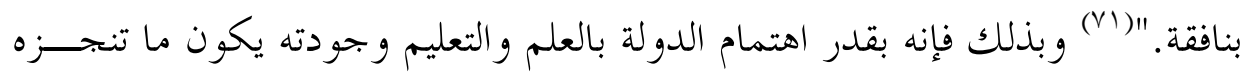
وتحققه في الأجيال القادمة.

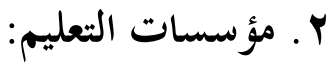

يذكر ابن خلدون نموذجاً من نماذج المؤسسات التعليمية، وهي مؤسسات التأليف

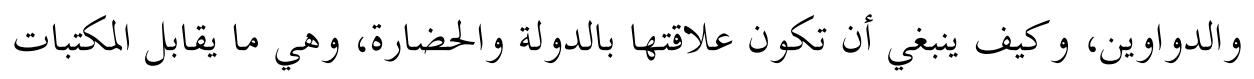

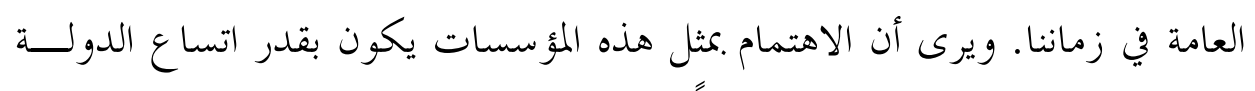

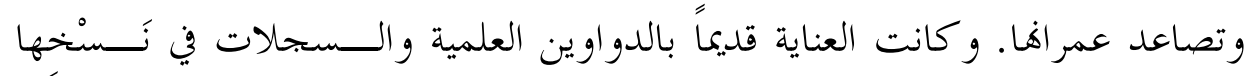

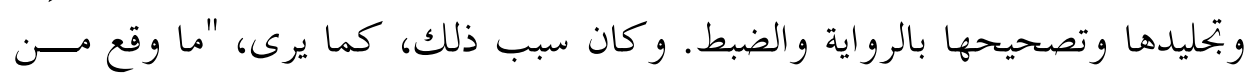

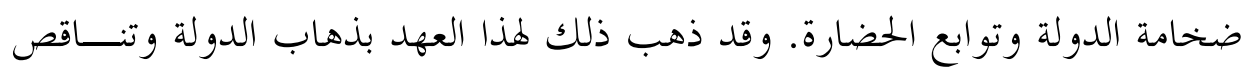

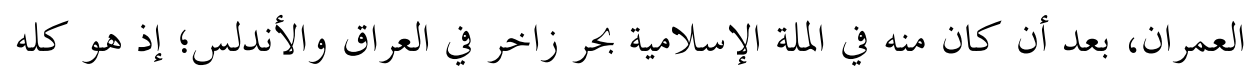

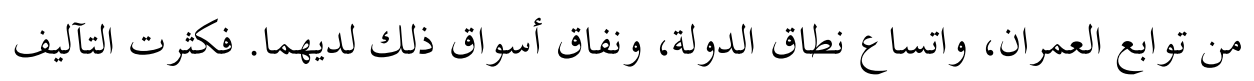

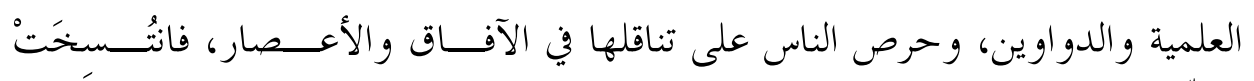

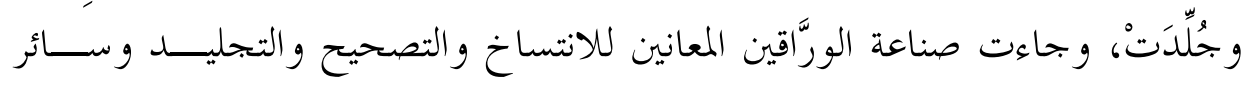

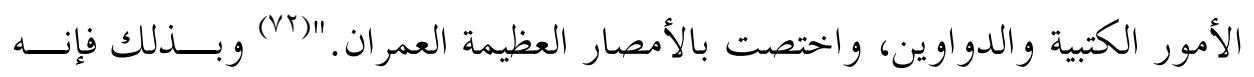

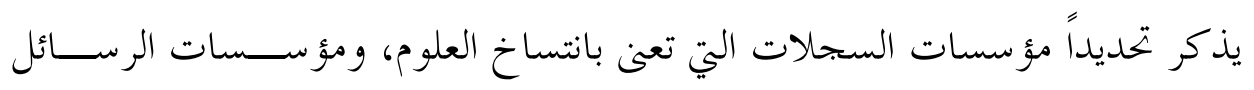


السلطانية التي تعنى بالمكاتبة و المراسلة، ومؤسسات التآليف التي قتتم بزيــادة الكـــــ

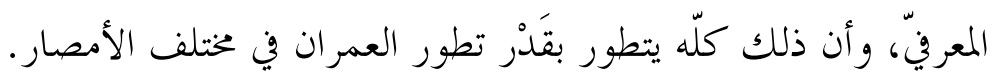

\section{ب. البيئة وأثرها في العلم والتَّعُّم و التعليم:}

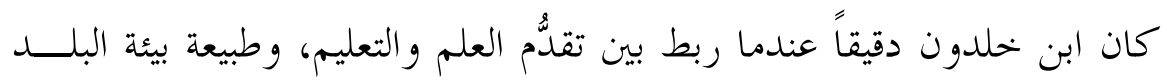

المتمثلة في مستوى عمراها وتقدم حضارةما. و بذلك فهو يرى أنه كلما كانت البيئسـة

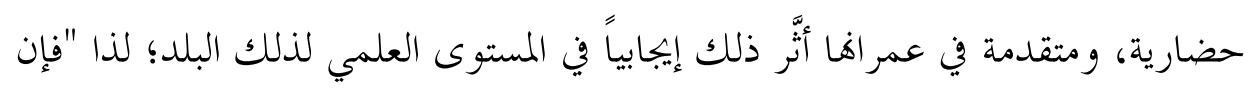

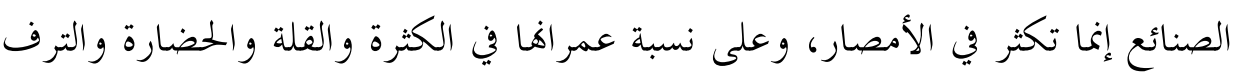

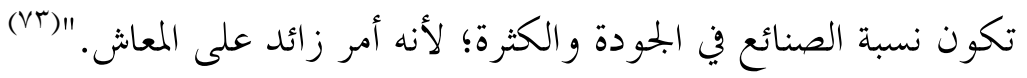
ويوضح هذه المسألة بمثال على ذلك، وهو حال بغداد وقرطبة و القيروان و البصرة

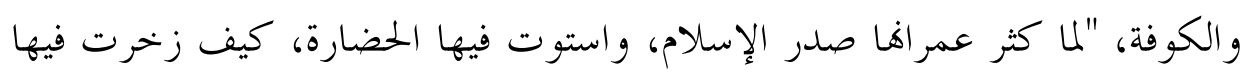

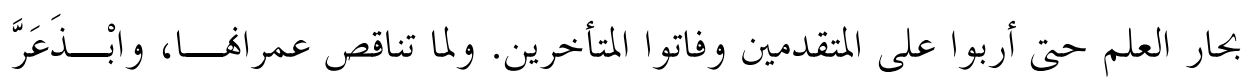

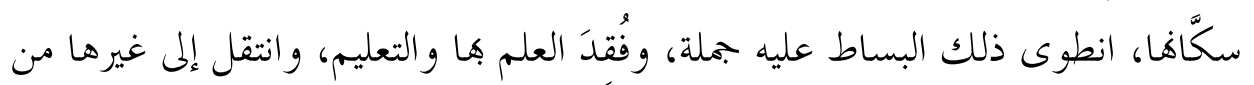

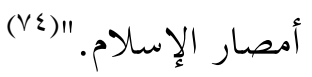

خحتمة: - م

من خلال هذا العرض تتضح أهم معالم الفكر التربويّ عند ابن خلدون. فقد قدم

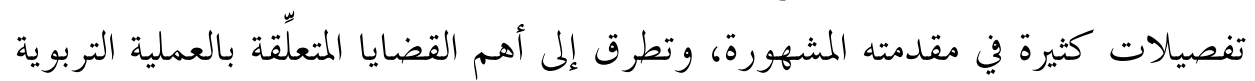

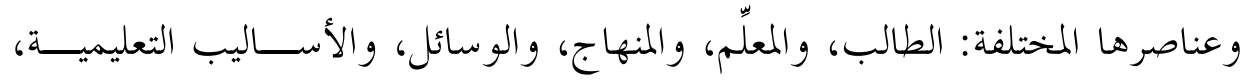

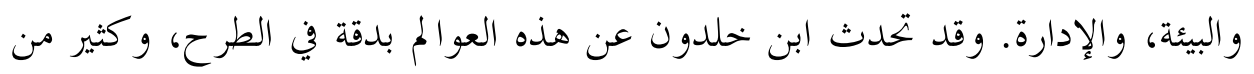

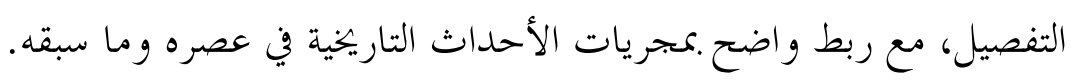


وقد سبق ابن خلدون في بعض الأفكار التربوية، علماء في التربية كثيرون، مــن

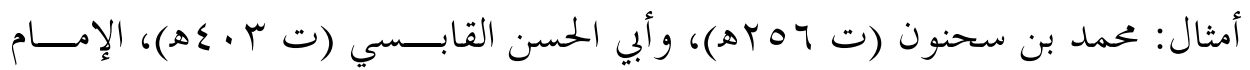

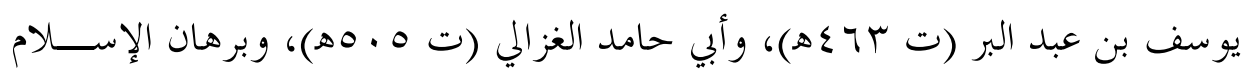

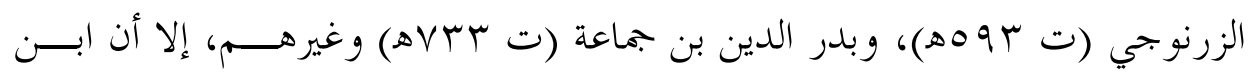
خلدون قد تميز عنهم .مسألتين أساسيتين:

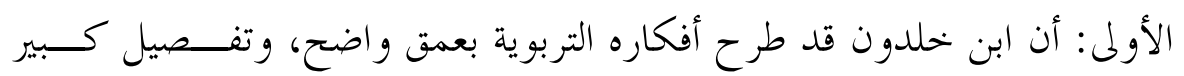

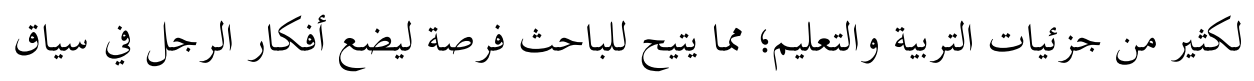

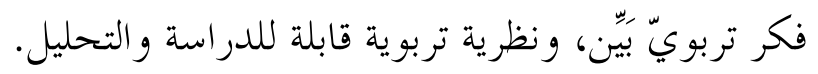

الثانية: أنه وضع أفكاره في سياق فكر أكبر وأعم من المنظومة التربوية الكبرى في

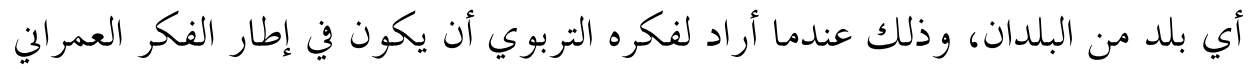

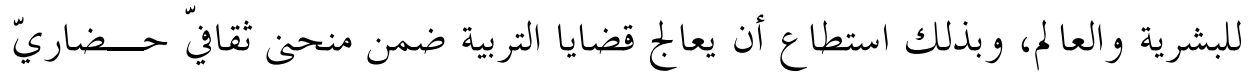

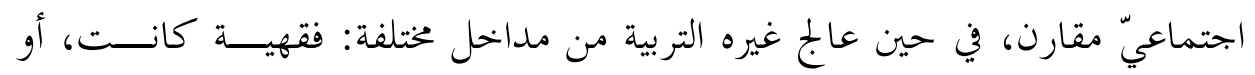

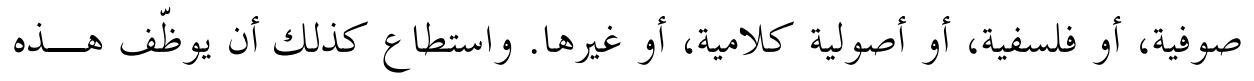

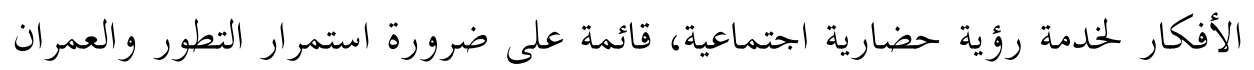

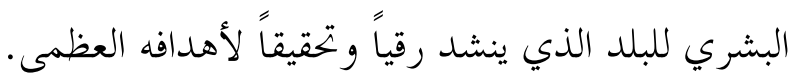

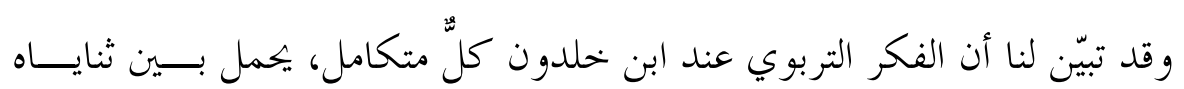

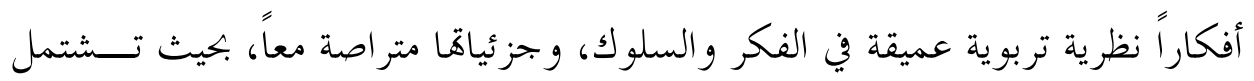

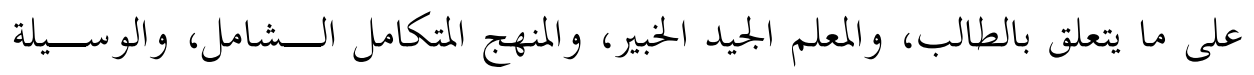

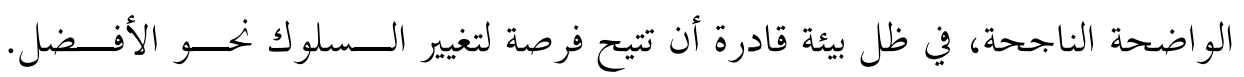

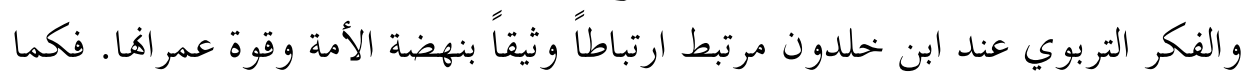

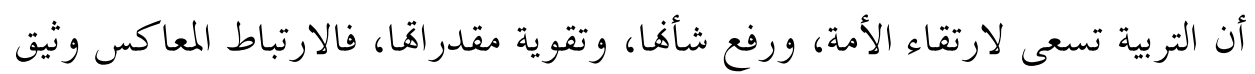

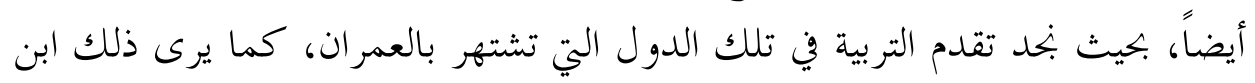

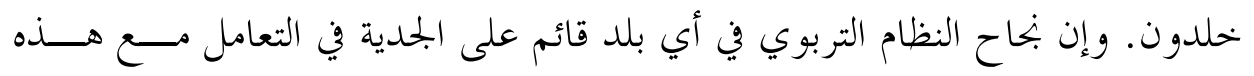

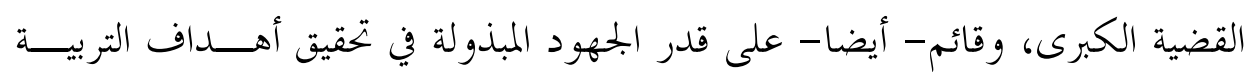


الكبرى، في صنع الإنسان الصالح، وعلى قدر الإيمان بضرورة الاستمرار نهو تطــــير

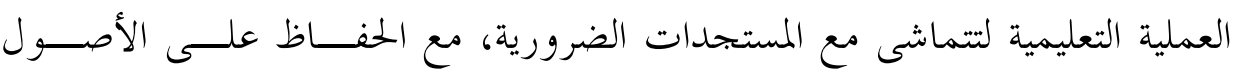

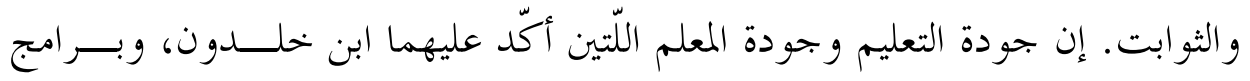
الإصلاح التربويّ المستمرة، كفيلة بتطوير النظام التربوي نهو الأفضل النعل.

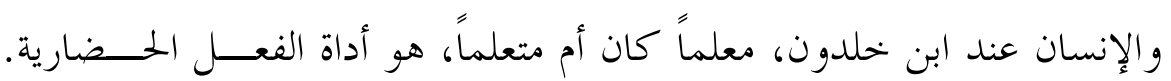

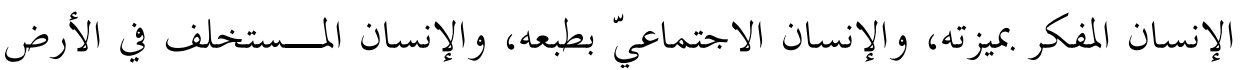

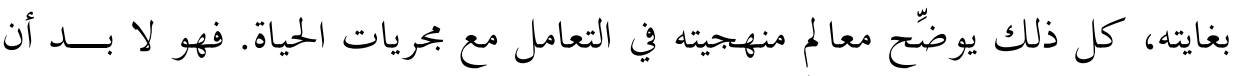

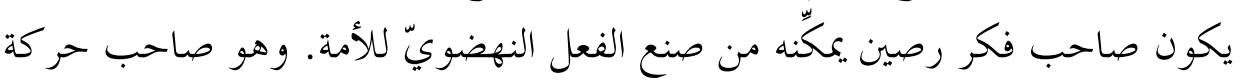

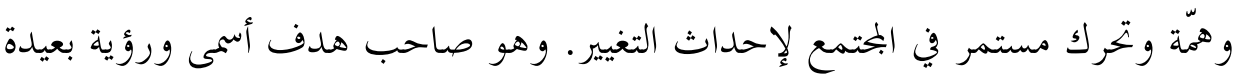

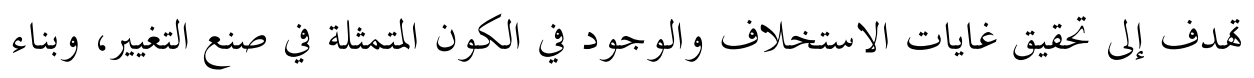

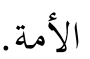

و العلم عند ابن خلدون شرف وكرامة، يجلب لصاحبه الرفعة والمكانة، والتربيسـة

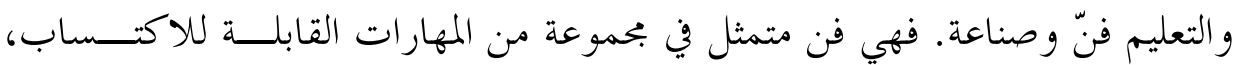

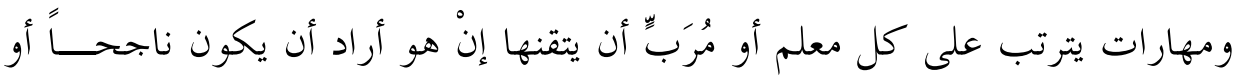

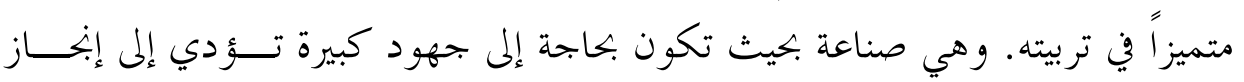

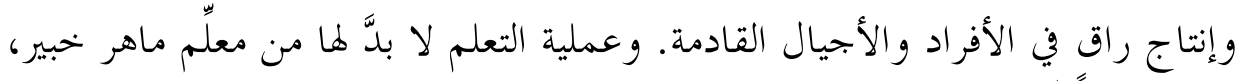

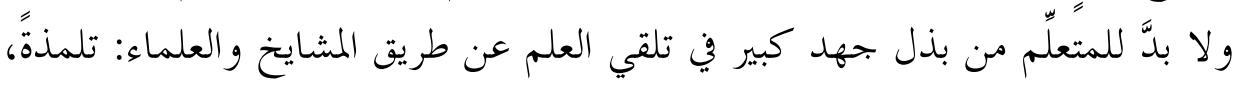

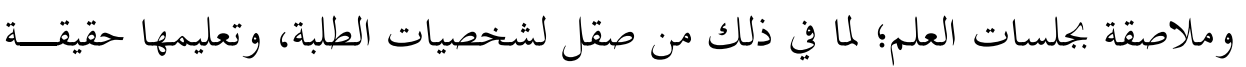

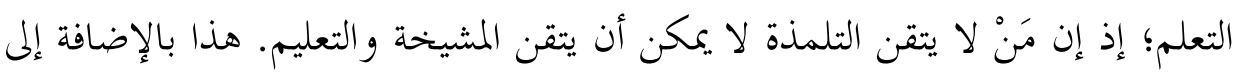

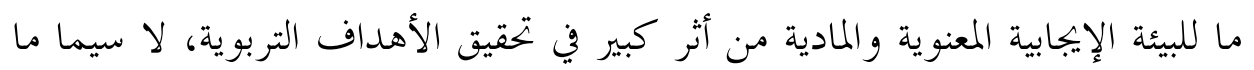

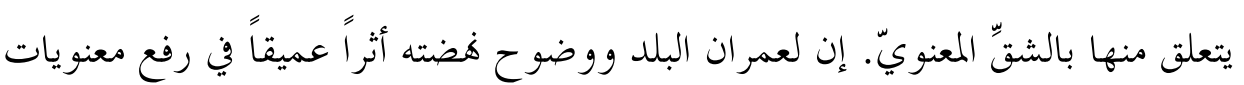

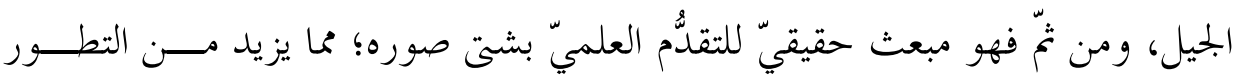
و النهوض. 
هذه بعض اللمحات والأفكار التربوية التي أمكن الخروج هـا من مقدمسـة ابــن فئ

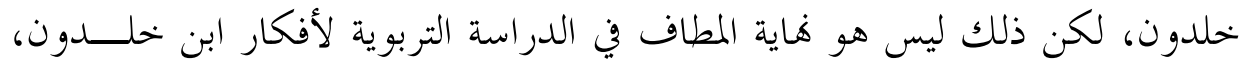

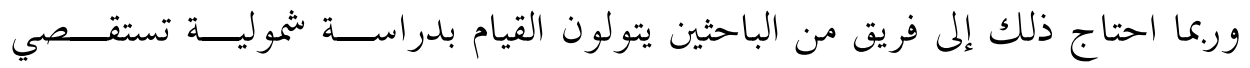

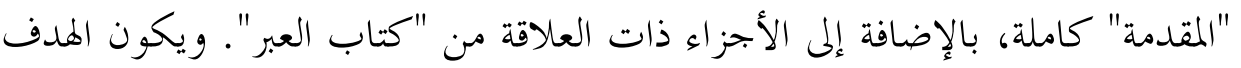
من ذلك الخروج بمنظومة ابن خلدون المتكاملة في التربية.

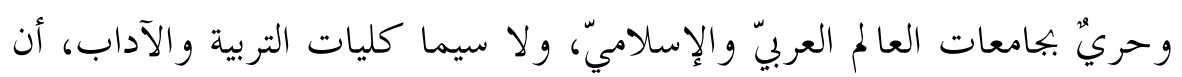

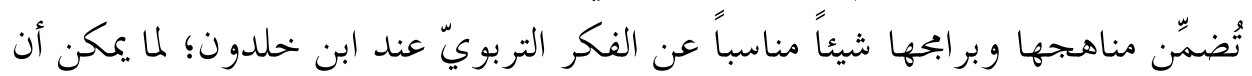

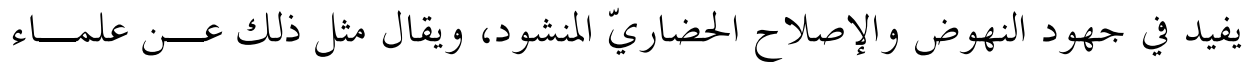

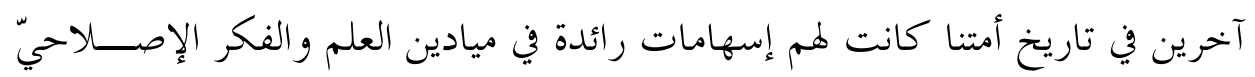
و والتجديديّ.

واختيار الفكر التربويّ عند ابن خلدون لا يقلل من إسهاماته وعطائه الفكريّ في

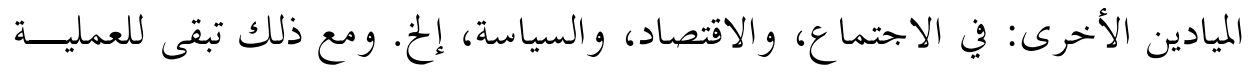

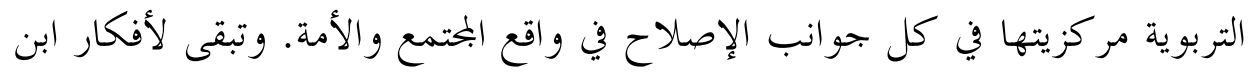

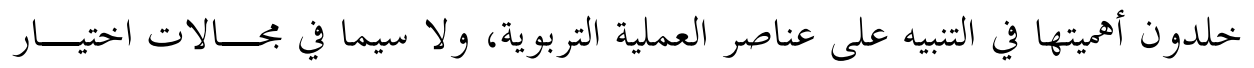

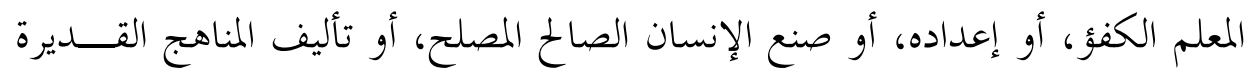

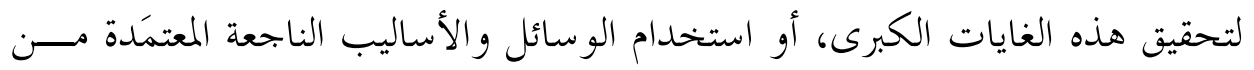

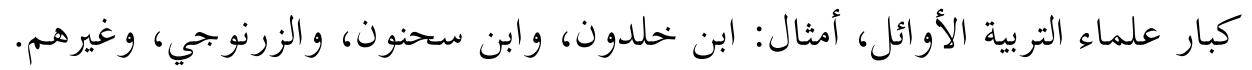

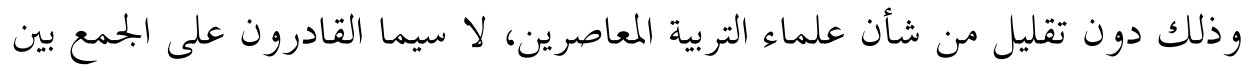

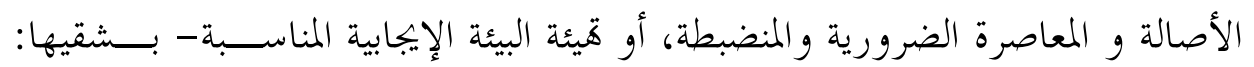

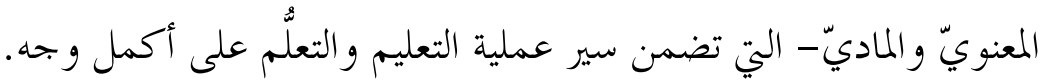

